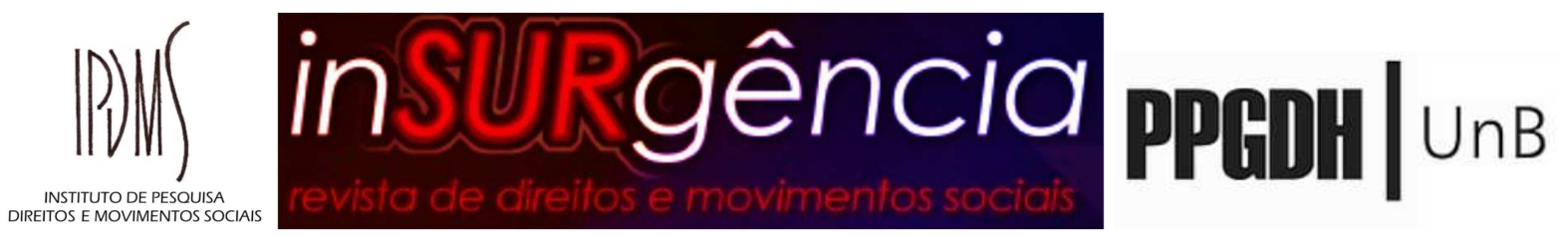

\title{
Função social da propriedade urbana e a luta pelo direito à cidade: uma análise a partir da experiência da missão em defesa do direito humano à moradia digna nas ocupações urbanas da cidade de São Leopoldo (RS)
}

The social function of urban property and the city rights struggle: an analysis from the mission in defence to decent housing in São Leopoldo city's urban occupations (RS)

Karina Macedo Fernandes ${ }^{1}$

Cristiano Muller ${ }^{2}$

(c) $)_{\mathrm{EY}}$ This work is licensed under a Creative Commons Attribution 4.0 International License.

Resumo: Este trabalho analisa a Missão em Defesa do Direito à Moradia Digna nas Ocupações Urbanas na cidade de São Leopoldo (RS) para responder em que medida ocorre a violação do direito humano à moradia digna mediante o descumprimento da função social da propriedade urbana. As hipóteses são que o descumprimento da ordem jurídico-urbanística gera a violação progressiva do direito humano à moradia digna e que as atividades de missão, ao monitorarem situações de vulnerabilidade, contribuem para a radicalização da democracia e da concretização do direito à cidade a partir da consolidação de um agir cotidiano de direitos humanos. Sob o método analítico-indutivo e da pesquisa ação, parte-se do relatório da missão analisada para apresentar categorias decisivas à discussão sobre ocupações urbanas.

Palavras-chave: Ocupações urbanas. Missões de Monitoramento. Direito à moradia. Direito à cidade.

\footnotetext{
${ }^{1}$ Doutora e mestra em Direito Público pela Universidade do Vale do Rio dos Sinos - UNISINOS. Graduada em Direito pela Universidade Federal do Rio Grande - FURG. Integrante do Núcleo de Direitos Humanos da UNISINOS. Desenvolve pesquisas na área de Direito, com ênfase em direitos humanos, direito à cidade e pensamento descolonial. Email: karimfernandes@gmail.com. ORCID: https://orcid.org/0000-0003-1730-2702.

${ }^{2}$ Possui graduação em Ciências Jurídicas e Sociais pela Pontifícia Universidade Católica do Rio Grande do Sul (1996), doutorado em Direitos Humanos e Desenvolvimento - pela Universidad Pablo de Olavide (2007) de Sevilha, Espanha e pós-doutorado pela Pontifícia Universidade Católica do Rio Grande do Sul (2010). Email:. ORCID:
} 


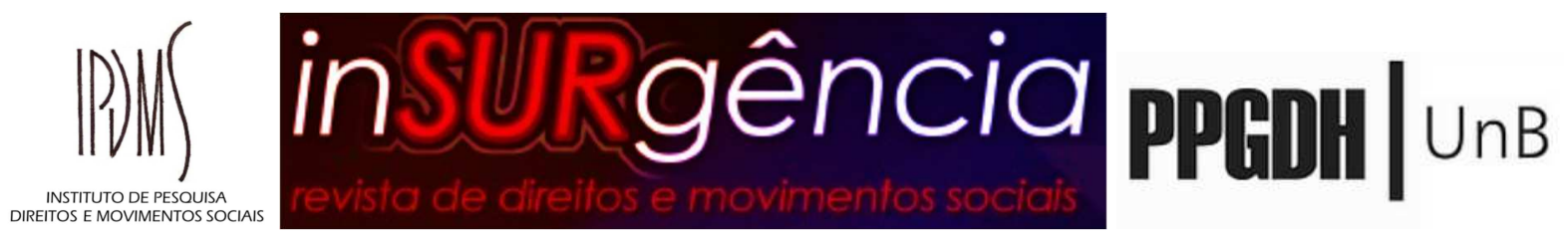

Abstract: This workpaper analyses the Mission in Defence to Decent Housing in São Leopoldo city's Urban Occupations (RS) to answer the extent to which the human right to decent housing is violated through the social function of urban property's violation. The hypotheses are that the legal-urbanistic order non-compliance generates a progressive violation of the human right to decent housing and that mission activities, by monitoring situations of vulnerability, contribute to the radicalization of democracy and the realization of the right to the city from the consolidation of daily human rights action. Under the analytical-inductive method and the action-research, we start from the analysed mission report to present important categories for the discussion on urban occupations.

Keywords: Urban occupations. Monitoring missions. Right to decent housing. Right to the city.

\section{Introdução}

O monitoramento do cumprimento dos tratados e pactos de direitos humanos firmados pelo Brasil é fundamental para a garantia e efetivação dos direitos das pessoas e comunidades vulneráveis que demandam proteção estatal. Existem várias formas de efetuar esse monitoramento, como ocorre, por exemplo, pela fiscalização das rubricas orçamentárias do poder público e de sua aplicação, pela pesquisa legislativa e de decisões judiciais, pela fiscalização da execução das políticas públicas. Porém, nenhum monitoramento é tão fidedigno e conduz a uma resposta tão contundente como a realização de uma atividade de missão num determinado território para verificação de uma situação-conflito.

Uma atividade de missão garante a possibilidade de se aferir de modo vivo e em movimento o cumprimento ou não de um ou mais preceitos de direitos humanos. No caso em concreto e que embasa o presente artigo, analisaremos a Missão em Defesa do Direito à Moradia Digna nas Ocupações Urbanas na cidade de São Leopoldo (RS). A metodologia de missões é inspirada nas iniciativas dos Relatores temáticos das Nações Unidas e foi implementada no Brasil pela Plataforma DHESCA Brasil. Será a partir do relatório da missão realizada na cidade de São Leopoldo que conduziremos esta escrita, utilizando, para tanto, categorias teóricas decisivas à discussão sobre ocupações urbanas, que são a função social da propriedade, o direito à moradia digna e o papel do sistema de justiça na garantia dos direitos humanos. 


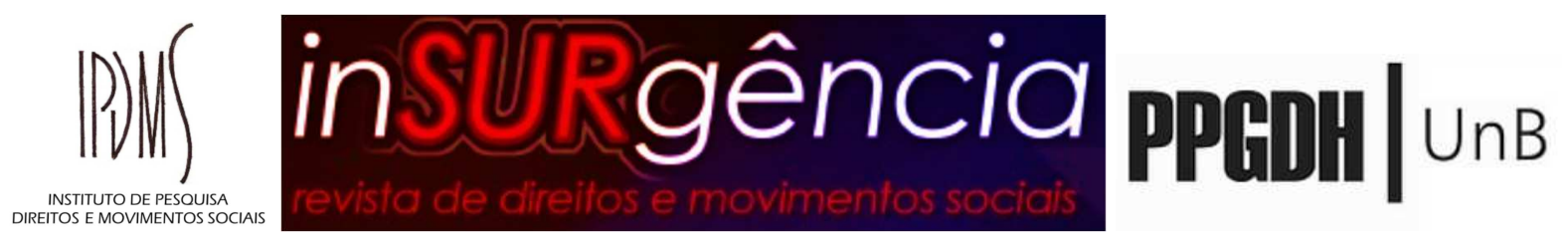

Esse artigo pretende, portanto, fortalecer ainda mais a atividade prática, viva e de movimento realizada no âmbito da missão a partir da contextualização teórica das principais conclusões da missão. Como nos ensina David Sánchez Rubio:

[...] el efecto expropiatorio y de secuestro tanto de la capacidad de lucha constituyente popular como de la acción social y cotidiana se manifiesta en la criminalización de las actuaciones ciudadanas individuales y colectivas a favor del cumplimiento de derechos normativizados, pero no efectivizados estatalmente (como el derecho a una vivienda, el derecho a la tierra, la función social de la propiedad o el derecho al trabajo), así como también con el desprestigio y la mala prensa de las luchas instituyentes por nuevos o ancestrales derechos no normativizados constitucionalmente, pero legitimados por su justicia referida a la materialidad diferenciada de condiciones de existencia e identitarias (por ejemplo, determinados derechos colectivos de naciones y pueblos indígenas o derechos ambientales y derechos sexuales). (SÁNCHEZ RUBIO, 2014):

Por isso, é importante identificar as principais condições, indicadores e características sociais vividas pelas pessoas no Brasil e na cidade de São Leopoldo (RS), de maneira a responder em que medida ocorre a violação do direito humano à moradia digna na cidade de São Leopoldo (RS), mediante o descumprimento da função social da propriedade urbana enquanto uma das principais diretrizes do direito urbanístico no Brasil. As hipóteses que fundamentam esta pesquisa são que o descumprimento da ordem jurídico-urbanística, por meio da inobservância da função social da propriedade urbana, gera a violação progressiva do direito humano à moradia digna, e que as atividades de missão, ao monitorarem situações de vulnerabilidade social, especialmente em relação ao direito à moradia adequada, contribuem para a radicalização da democracia e a concretização do direito à cidade a partir da consolidação de uma cultura de direitos, de um agir cotidiano de direitos humanos.

Pra tanto, pretendemos, sob o método de pesquisa analítico indutivo e da pesquisa-ação, demonstrar a violação do direito à moradia digna na cidade de São Leopoldo a partir do descumprimento da função social da propriedade urbana observado na missão em defesa do direito humano à moradia digna nas ocupações urbanas da cidade, e o fazemos por meio de processos marcados uma correlação entre as reflexões teóricas e a experiência prática, nos termos propostos por Fals Borda (1970), para quem devem ser tomados em conta os grupos sociais e as condições políticas locais do contexto da pesquisa como preponderantes a pesquisas destinadas à transformação social. Irão fazer parte desse mapeamento indicativos importantes como o déficit habitacional, a precariedade urbana, o índice de desenvolvimento humano, entre outros que relacionados com a realidade documentada pela missão realizada nas ocupações 


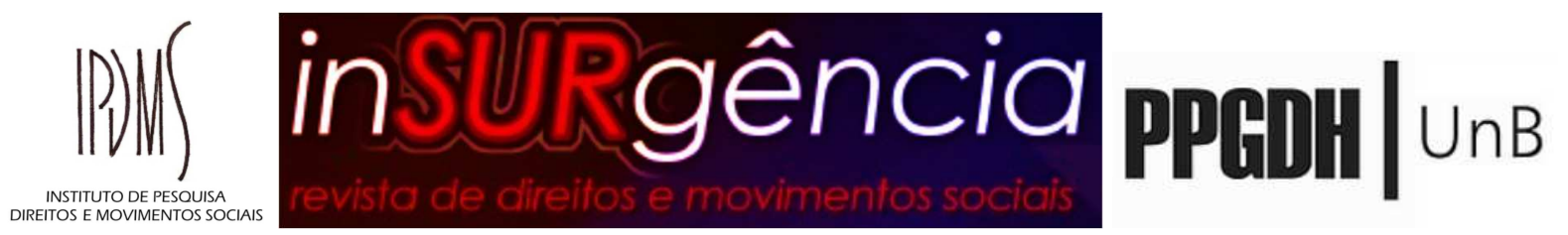

urbanas ameaçadas de despejo e que podem nos informar da realidade vigente na região.

A partir daí, os seguintes temas são problematizados pelo artigo: a função social da propriedade, o direito à cidade e o papel do poder judiciário na garantia dos direitos humanos. A função social da propriedade aparece em função do direito à cidade denuncia a assimetria entre a realidade e o que duramente foi conquistado na legislação brasileira ao longo do tempo referente às garantias ao direito à cidade, como o acesso à terra, à gestão do solo, aos instrumentos jurídicos e políticos de gestão da cidade para todos e todas e que estão previstos no Estatuto da Cidade. Já o Poder Judiciário é trabalhado no artigo a partir do protagonismo das Ocupações Urbanas na cidade de São Leopoldo (RS), que demandaram proteção contra os despejos e promoção do direito à moradia digna para milhares de pessoas somente na cidade.

Estima-se que aproximadamente 10 mil pessoas estejam ameaçadas de despejo na cidade de São Leopoldo, muito por conta de moradias havidas sob as redes de alta tensão e que também estão judicializadas. Assim, o artigo apresenta as possibilidades de atuação do sistema de justiça, especificamente do judiciário, na garantia de efetivação dos direitos humanos, por meio das práticas de mediação de conflitos, aplicação dos enunciados internacionais de direitos humanos e da Resolução ${ }^{\circ} 10$ do Conselho Nacional de Direitos Humanos, que dispõe sobre soluções garantidoras de direitos humanos e medidas preventivas em situações de conflitos fundiários coletivos rurais e urbanos. (BRASIL, 2018).

A complexidade do fenômeno dos despejos denunciados no relatório da missão realizada na cidade de São Leopoldo importa numa reflexão muito mais extensa sob muitas outras categorias teóricas igualmente importantes e que podem ser objeto de análise e de reflexão teórica também afeitas aos direitos humanos, como as violações ao direito à educação das crianças e adolescentes que perdem o ano letivo em função de um despejo; a perda de renda e trabalho dos afetados por um despejo; a violação do direito à saúde psicológica e emocional que um despejo acarreta; a perda de laços, sociabilidade e de território pelos afetados, que vai muito mais além da perda de uma casa. Todavia, esse artigo se limitou em tratar de pontos que apareceram na missão como decisivos e estratégicos na proteção do direito humano à moradia digna das ocupações urbanas da cidade de São Leopoldo (RS).

2. Um pouco do contexto jurídico-urbanístico e do direito à moradia digna no Brasil, em especial na cidade de São Leopoldo (RS) 


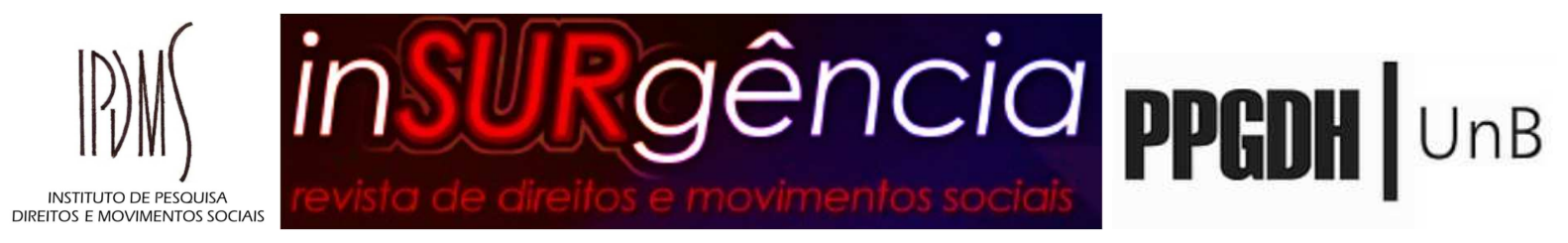

O direito à moradia digna é o direito que todo ser humano tem de viver em um lugar com segurança, paz e dignidade. A moradia adequada compõe o direito a um padrão de vida adequado e tem como principais pressupostos o acesso a serviços, equipamentos e infraestrutura urbana, como água, saneamento, energia, rede de transporte público. Tem como características intrínsecas a habitabilidade, a localização, a segurança legal da posse, o acesso econômico, a não discriminação e a adequação cultural (MOURA; MOTA, 2015, p. 1.307).

Isso significa dizer que a moradia adequada é aquela que possui condições de salubridade, de segurança e de instalações sanitárias adequadas; que é atendida pelos serviços públicos essenciais, dentre os quais água, esgoto, energia elétrica, iluminação pública, coleta de lixo, pavimentação e transporte coletivo, e com acesso aos equipamentos sociais e comunitários básicos, como postos de saúde, praças de lazer e escolas públicas, além de possuir um tamanho mínimo para ser considerada habitável e guardar proximidade com meios de mobilidade que possibilitem o exercício da força de trabalho das cidadãs e dos cidadãos. Também é possível afirmar que a moradia é o lugar das relações sociais. "Toda família precisa de uma moradia. Todos moram em algum lugar, ainda que seja numa mansão em condomínio fechado ou num barraco sob um viaduto" (MARICATO, 2009, p. 36), o que permite afirmar que o direito à moradia tem um viés eminentemente pessoal, diretamente relacionado à dignidade da pessoa humana e ao exercício de uma vida digna.

Absolutamente correlato ao direito à moradia por ser o espaço territorial da habitação, reivindicamos a noção de direito à cidade, que é constituída por três princípios fundamentais: o exercício pleno da cidadania, a gestão democrática da cidade e a função social da cidade e da propriedade urbana. Os dois primeiros correspondem à realização de todos os direitos humanos e fundamentais e da garantia da dignidade e do bem-estar coletivo dos cidadãos equanimemente, garantindo-se o controle e a participação de todas as pessoas que moram na cidade, por intermédio de formas diretas e representativas no planejamento e governo das cidades. Já a função social da cidade e da propriedade urbana se refere à subordinação do direito de propriedade aos direitos coletivos e sociais a fim de garantir o uso justo e equilibrado do espaço urbano. (ROLNIK, 2013).

Propomos aqui uma leitura do conceito de "cidade como sendo projeção da sociedade sobre um local, isto é, não apenas sobre o lugar sensível como também sobre o plano específico, percebido e concebido pelo pensamento, que determina a cidade", conforme definido por Henri Lefebvre na obra Direito à Cidade (2016, p. 66). Para isso, evidenciamos o papel histórico da 


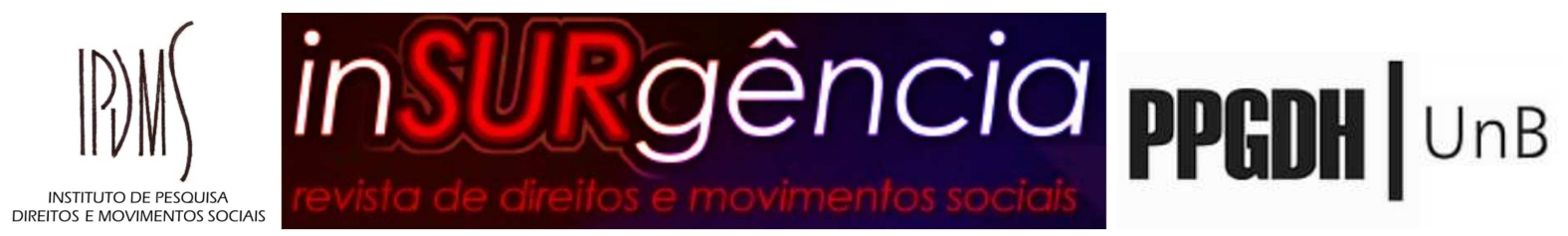

cidade na aceleração do processo de circulação do capital. Nesse sentido, a cidade se projeta conforme a historicidade de cada tempo, sobre o espaço social em que se organiza a sociedade urbana e que têm no planejamento forte expressão institucional de controle do Estado, por meio do direito: "O que há de mais forte e poderoso atrás da ideia de planejar a cidade, é sua correspondência com uma visão da cidade como algo que possa funcionar como um mecanismo de relojoaria, mecanicamente", nas palavras de Raquel Rolnik (2013, p. 61, grifo nosso).

Atualmente, o Brasil enfrenta um déficit habitacional de 7,757 milhões de moradias (FGV, 2018), indicador evidenciado quando ocorre pelo menos uma de quatro situações: domicílios precários, que são os locais sem as condições adequadas de vida digna; coabitação, que significa estar estabelecido um excedente de famílias em relação ao número de domicílios existentes; domicílios cujo valor do aluguel é superior a $30 \%$ da renda domiciliar total [excedente de aluguel]; e domicílios alugados com mais de três habitantes utilizando o mesmo cômodo [adensamento excessivo] (BRASIL, 2013; FJP, 2018). Diante desse cenário, estudos sugerem que o Brasil necessita prover mais de 12 milhões de moradia para reduzir o déficit habitacional e atender as famílias que se formarão nos próximos 10 anos (FJP, 2018).

O déficit se concentra em famílias com renda familiar de até um salário mínimo (40,6\%), nas famílias com renda familiar entre um e três salários mínimos $(51,1 \%)$, de maneira que as famílias com renda superior a três salários mínimos representam 8,3\% dos dados do déficit habitacional. Das regiões metropolitanas do Brasil, o déficit habitacional mais crítico se encontra nas regiões Sudeste e Nordeste (FJP, 2018).

Na região metropolitana de Porto Alegre, o déficit habitacional era de mais de 96 mil famílias em 2015, data do estudo mais recente (FJP, 2018), número que aumentou 25\% em relação a 2012 e que coloca a capital do estado do Rio Grande do Sul em parâmetro equiparável às piores estatísticas dentre as regiões Sul e Sudeste (FJP, 2018). A situação de inadequação fundiária na região metropolitana de Porto Alegre era de 43.742 domicílios em 2015 e no mesmo período foram registrados 4.301 domicílios sem banheiro e 39.952 domicílios urbanos carentes de infraestrutura básica na região (FJP, 2018).

Importante observar que 28.900 pessoas atingidas pelo déficit habitacional na região metropolitana de Porto Alegre recebiam até três salários mínimos em 2015 e a região possuía um total de 158.813 domicílios vagos com potencial de serem ocupados (FJP, 2018). As cidades de Canoas, São Leopoldo e Novo Hamburgo, que possuem mais de 200 mil habitantes, 


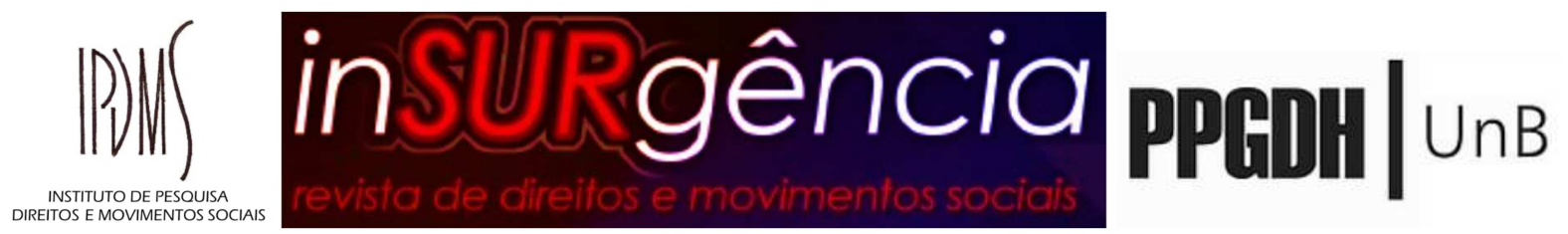

aparecem nas primeiras posições do déficit absoluto, como podemos visualizar no gráfico abaixo:

Figura 1: Gráfico do déficit habitacional urbano em relação à população do Vale dos Sinos (2010) Déficit habitacional urbano absoluto em relação à população do Vale do Sinos (2010)

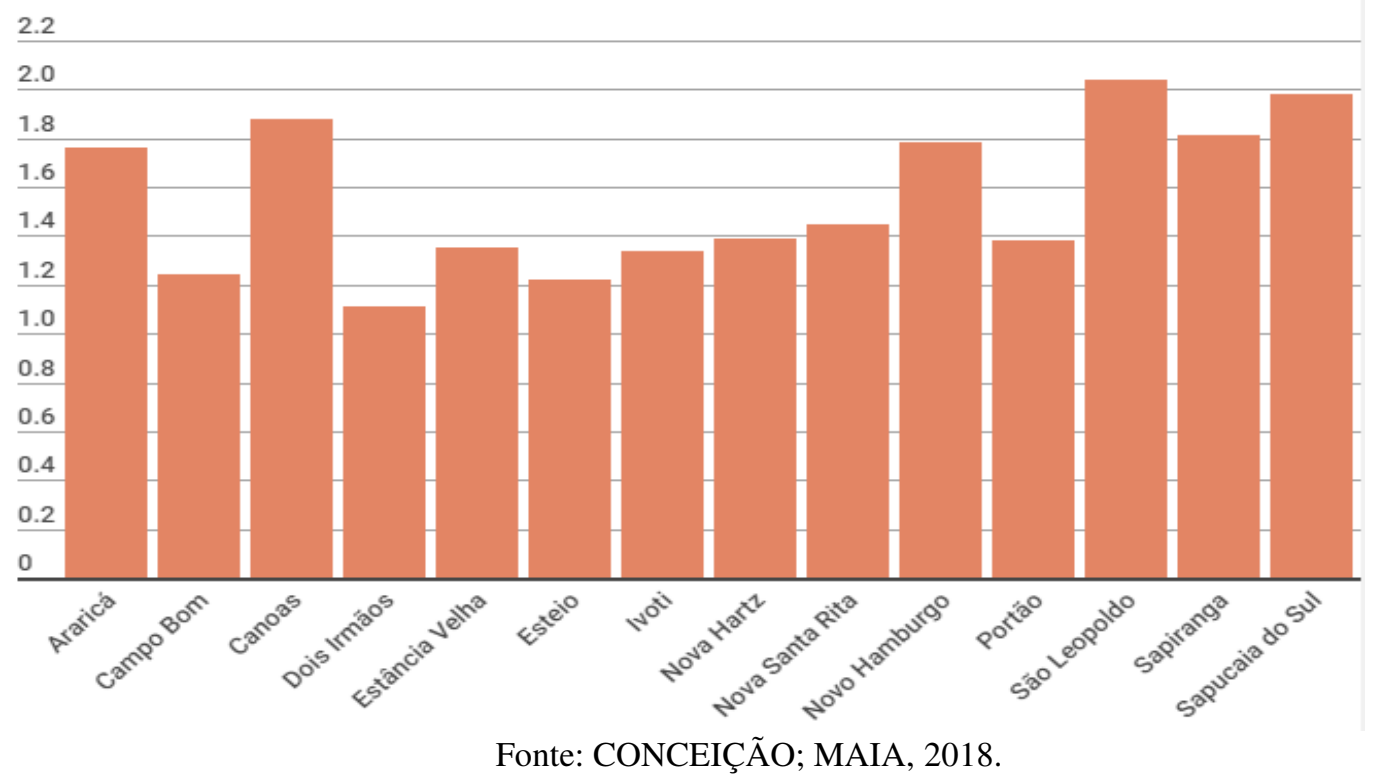

O déficit habitacional da região do Vale dos Sinos é causado predominantemente por ônus excessivo com aluguel (60\%) e precariedade domiciliar (26\%), que atinge famílias com renda de até três salários mínimos e que destinam $30 \%$ ou mais da sua renda para aluguel urbano (CONCEIÇÃO; MAIA, 2018). Tais dados revelam que, apesar de garantidos, o direito à moradia e todos os seus direitos necessariamente correlatos, como o direito à cidade, à saúde $\mathrm{e}$ à vida digna a realidade da habitação urbana na região metropolitana de Porto Alegre é de extrema vulnerabilidade. 


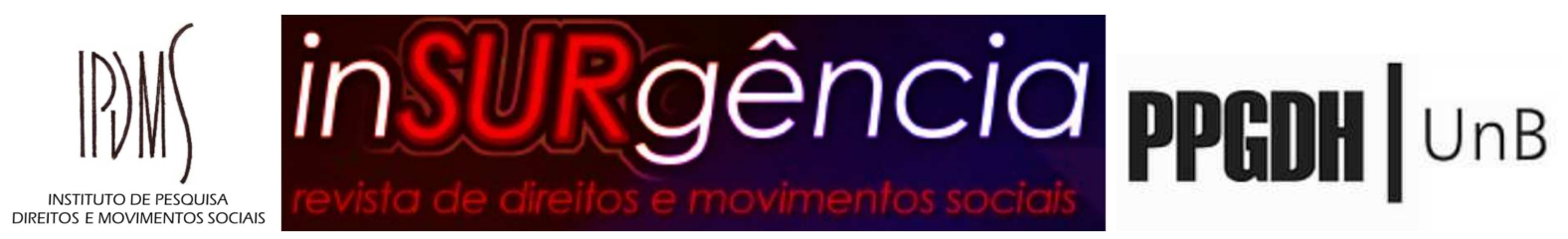

A ausência de infraestrutura urbana básica - especialmente no que tange a saneamento, atendimento à saúde, segurança e educação -, a ausência de controle sobre os preços do aluguel, a especulação imobiliária e a exposição de diversas regiões a riscos ambientais são questões diretamente associadas ao déficit habitacional e que compõem um contexto generalizado de vulnerabilidades, de aumento significativo de despejos e deslocamentos compulsórios, somado às crises do capitalismo financeiro pós-colapso do sistema financeiro globalizado de 2008. Isso tudo nos coloca diante da construção de um padrão colonial de cidade (ROLNIK, 21015), de uma hegemonia ideológica e prática de um modelo de urbanização sem planejamento territorial, no qual a habitação se transforma em ativo financeiro.

Cidade fundada no ano de 1824 e considerada o "berço da colonização alemã do país" (PREFEITURA DE SÃO LEOPOLDO, 2020), São Leopoldo possui uma população de 229.678 pessoas e área de $102,3 \mathrm{~km}^{2}$, segundo dados de 2016 e 2014, respectivamente (PREFEITURA DE SÃO LEOPOLDO, 2020). A tabela abaixo indica outros dados estatísticos importantes da cidade.

Tabela 1: Resumo estatístico do Município de São Leopoldo (RS)

\begin{tabular}{|l|r|}
\hline $\begin{array}{l}\text { Taxa de analfabetismo de pessoas com } 15 \\
\text { anos ou mais (2010) }\end{array}$ & $\mathbf{3 , 1 7 \%}$ \\
\hline Expectativa de vida ao nascer (2010) & 76,65 anos \\
\hline Coeficiente de Mortalidade Infantil (2016) & 11,50 por mil nascidos vivos \\
\hline PIB & $\mathrm{R} \$ 6.932 .552,24(\mathrm{mil})(2015)$ \\
\hline & $\mathrm{R} \$ 2.075 .185 .217(2003)$ \\
\hline
\end{tabular}

Fonte: Fundação de Economia e Estatística (FEE), 2018.

O Índice de Desenvolvimento Humano municipal (IDHM) da cidade foi de 0,656 em 2000 e passou para 0,739 em 2010 (ATLAS ..., 2020). Isto significa que o município passou para um patamar de alto desenvolvimento humano, principalmente pelo aumento da expectativa de vida dos seus habitantes, seguido pela dimensão da renda e, por último, educação, segundo o Atlas do Desenvolvimento Humano (2020).

A população entre 15 e 24 anos em situação de vulnerabilidade social, isto é, que reside em domicílios com renda per capita igual ou inferior a meio salário mínimo, era de 9.648 jovens em 2000 para 6.846 em 2010 (ATLAS ..., 2020). Por outro lado, a população de mulheres que 


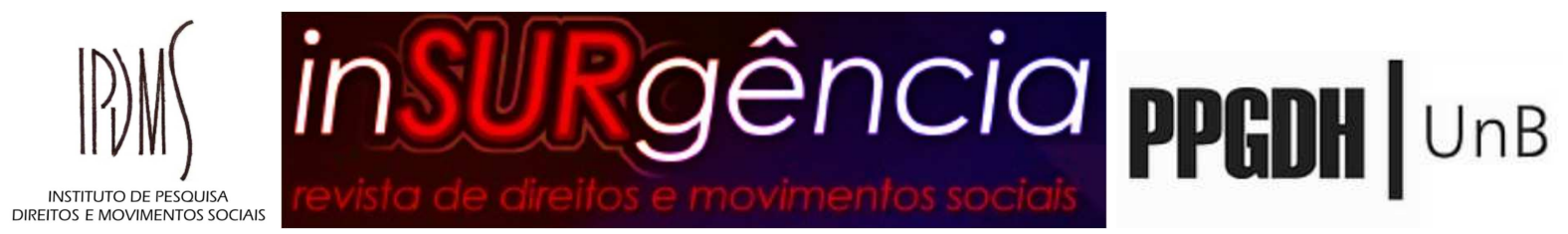

eram chefes de família e que possuíam pelo menos um filho menor de 15 anos de idade residindo no domicílio era de 4.704 em 2000, passando para 10.298 em 2010, contabilizando um aumento de 119\%, conforme o Índice de Vulnerabilidade Social (IVS). Em adição, a porcentagem de crianças de até 14 anos que vivem em domicílios em que nenhum dos moradores tem o ensino fundamental completo subiu de $28 \%$ em 2000 para 43,9\% em 2010 (ATLAS ..., 2020).

Os projetos de investimento em infraestrutura e habitação de interesse social na região metropolitana de Porto Alegre via financiamento governamental foram consideravelmente expandidos no período compreendido entre 2007 e 2016 (MARTINS, 2017), e seus financiamentos ocorreram principalmente por meio de recursos provenientes de operações de crédito e repasses do Orçamento Geral da União (OGU) e da Caixa Econômica Federal (CEF). Tendo em vista a distribuição dos recursos entre os municípios da região metropolitana de Porto Alegre, verificou-se uma concentração do total dos contratos equivalentes a tais investimentos neste período nas áreas de habitação, mobilidade e saneamento, apenas nos municípios de Porto Alegre (39,7\%), Canoas (18,6\%), São Leopoldo (7\%), Gravataí (5,7\%) e Novo Hamburgo $(5,4 \%)$ (MARTINS, 2017).

$\mathrm{Na}$ área de habitação, estes cinco municípios também somam mais de $75 \%$ do total de investimentos, sendo $26 \%$ referentes a Porto Alegre, 15,1\% a Canoas, 11,9\% a São Leopoldo, 9,4\% a Gravataí e 6\% a Novo Hamburgo (MARTINS, 2017). Na mobilidade urbana, 67,7\% dos recursos contratados foram destinados ao município de Porto Alegre, seguido de Canoas, com 20,9\% (MARTINS, 2017). Na área de saneamento, 75\% dos recursos correspondiam a contratações nos municípios de Porto Alegre, Canoas, São Leopoldo, Gravataí e Novo Hamburgo (MARTINS, 2017).

Tais circunstâncias, associadas ao resumo estatístico do déficit habitacional da região do Vale do Rio dos Sinos, tornam a cidade de São Leopoldo especialmente vulnerável em termos de habitação adequada. Nesse sentido, foram mapeadas cinco grandes ocupações urbanas, em que milhares de pessoas lutam pelo seu direito de habitar e viver dignamente, com saneamento, educação e saúde. Essas ocupações são denominadas Ocupação Justo, Ocupação Steigleder, Ocupação Vitória, Ocupação Anita e Ocupação Santa Marta e seus resumos estatísticos podem ser acompanhados nas tabelas que seguem: 


\section{PIVII)

\section{Ocupação Steigleder}

\begin{tabular}{l|l} 
Urbanização: & Nenhuma \\
\hline Água: & Os moradores buscam água em uma igreja no bairro vizinho.
\end{tabular}

Saneamento básico: Nenhum

Iluminação: $\quad$ Inexistente

Famílias: $\quad 211$

Trabalho: $\quad$ Maior parte, catadores de material reciclável.

Renda Média: $\quad \mathrm{R} \$ 300,00$

Fonte: OBSERVASINOS, 2019.

Tabela 3: Resumo estatístico da Ocupação Vitória, em São Leopoldo (RS)

\begin{tabular}{|l|l|}
\hline Urbanização: & Nenhuma \\
\hline Água: & $\begin{array}{l}\text { Rede irregular, com distribuição feita por mangueiras que se ligam } \\
\text { entre as casas. }\end{array}$ \\
\hline Saneamento básico: & Nenhum \\
\hline Iluminação: & Inexistente \\
\hline Famílias: & 245 \\
\hline Trabalho: & Variados, maior parte dos moradores trabalham fora de casa. \\
\hline Renda Média: & R $\$ 900,00$ \\
\hline
\end{tabular}

Tabela 4: Resumo estatístico da Ocupação Anita, em São Leopoldo (RS)

\begin{tabular}{|c|c|}
\hline \multicolumn{2}{|r|}{ Ocupação Cerâmica Anita } \\
\hline Urbanização: & Nenhuma \\
\hline Água: & $\begin{array}{l}\text { Rede irregular, com distribuição feita por mangueiras que ligam } \\
\text { todas as casas. }\end{array}$ \\
\hline Saneamento básico: & Nenhum \\
\hline Iluminação: & Inexistente \\
\hline Famílias: & 68 \\
\hline Trabalho: & $\begin{array}{l}\text { Variados, parte dos moradores trabalham fora de casa e parte são } \\
\text { catadores de material reciclável. }\end{array}$ \\
\hline
\end{tabular}




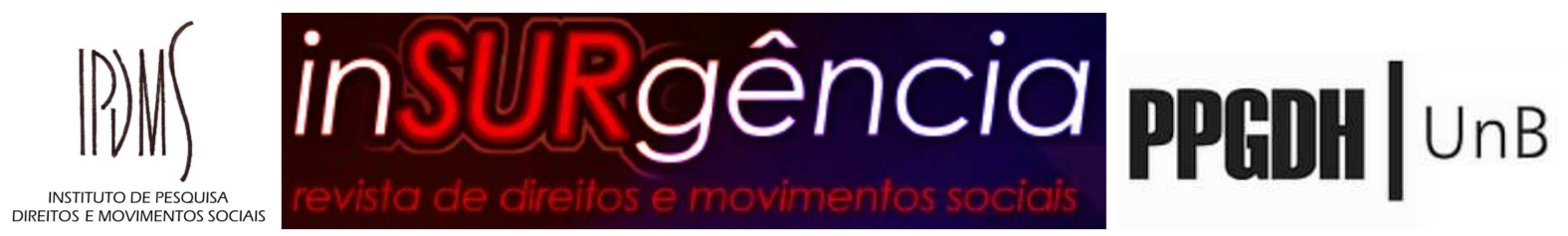

Renda Média: $\quad \mathrm{R} \$ 900,00$

Fonte: OBSERVASINOS, 2019.

Tabela 5: Resumo estatístico da Ocupação Justo, em São Leopoldo (RS)

\begin{tabular}{|l|l|}
\hline Urbanização: & Nenhuma \\
\hline Água: & Rede irregular e regiões sem abastecimento nenhum. \\
\hline Saneamento básico: & Nenhum \\
\hline Iluminação: & $\begin{array}{l}\text { Inexistente } \\
\text { Famílias: }\end{array}$ \\
\hline Trabalho: & $\begin{array}{l}\text { Maior parte dos moradores trabalham fora de casa e parte são } \\
\text { catadores de material reciclável. }\end{array}$ \\
\hline Renda Média: & variado \\
\hline
\end{tabular}

Nesse contexto, verificamos o estabelecimento de territórios populares na cidade, que foram autoconstruídos e que têm condições de serem habilitados para moradia, mas em que o Estado não chega para cumprir seu dever. Nesses lugares, as ocupações assumem o papel do Estado e realizam política urbanística para as pessoas que vivem ali, garantindo moradia, acesso à cidade, à saúde, à educação, ao saneamento básico, à cidadania e à cultura conforme assegurado pela Constituição e pela lei.

Como exemplo de benefícios trazidos por uma ocupação está o acesso ao centro da cidade, que representa, invariavelmente, significativas melhorias na condição de vida das pessoas ocupantes, que passam a ter condições de acesso à rede municipal de serviços de educação e saúde, bem como aos transportes públicos. Outro benefício significativo está em propiciar a formação de uma rede de solidariedade e participação social na cidade, conforme a autogestão dos moradores e sua organização para que a ocupação seja considerada um espaço de debate e de uso coletivo da cidade. Em uma ocupação, é comum ocorrer um empoderamento das pessoas que antes viviam em situação de abandono e exclusão e que passam não só a ter consciência de seus direitos e habilidades, como a defendê-los.

3. A missão em defesa do direito à moradia digna das ocupações urbanas na cidade de São Leopoldo (RS) 


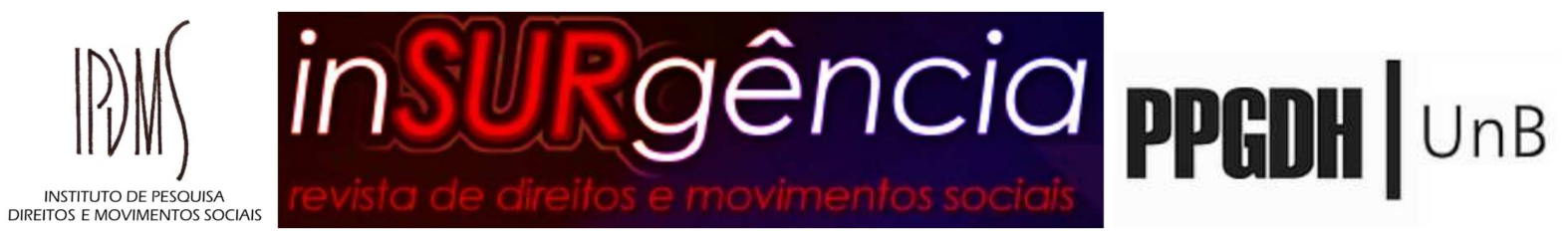

Nos dias 14 e 15 de março de 2019, foi realizada atividade de campo denominada de Missão em defesa do direito humano à moradia digna das Ocupações Urbanas na cidade de São Leopoldo/RS. As entidades que estiveram a frente dessa atividade foram: o Conselho Estadual de Direitos Humanos - Comissão de Terra e Território, o Centro de Direitos Econômicos e Sociais (CDES), o Movimento Nacional de Luta pela Moradia (MNLM), o Observatório de Políticas Públicas de São Leopoldo (OBSERVASINOS), o Instituto Humanitas Unisinos (IHU), a Universidade do Vale do Rio dos Sinos (UNISINOS), a Comunidade das Missionárias do Cristo Ressuscitado (CMCR), o Engenheiros Sem Fronteiras (ESM), o Movimento Justo, a Ocupação Steigleder e a Ocupação Vitória.

As atividades de missões são inspiradas na iniciativa dos Relatores Especiais da ONU. Elas funcionam como um mecanismo de monitoramento da situação dos direitos humanos no país, em que as Relatorias investigam denúncias, visitam locais onde existam violações aos direitos humanos e publicam relatórios com recomendações aos poderes responsáveis. Estes relatórios são apresentados às autoridades responsáveis pela temática objeto de missão tais como Secretarias de Governos, Poder Judiciário, Casas Legislativas e para as autoridades competentes locais. Muitas de suas recomendações transformaram-se em políticas públicas que auxiliaram na superação das violações e na melhoria de vida das populações cujos direitos foram violados.

Por meio dessa atividade de missão, objetiva-se o fortalecimento da cidadania e a radicalização da democracia no Brasil, a partir da consolidação de uma cultura de direitos e o monitoramento das situações de vulnerabilidade social no país:

[A]s missões também são de grande importância para as comunidades locais que têm os seus direitos violados, projetando-se como interlocutores válidos no espaço público, o que materializa vivências muitas vezes inéditas do ponto de vista da sua afirmação como detentores legítimos de direitos na sociedade. (PLATAFORMA DHESCA BRASIL, 2009, p. 124).

Entretanto, o fenômeno social dos despejos não é uma situação restrita à cidade de São Leopoldo, mas um fenômeno nacional e com grande potencial de violação de direitos humanos. Assim identificou a publicação Panorama dos Conflitos Fundiários Urbanos no Brasil (FNRU, 2019): 


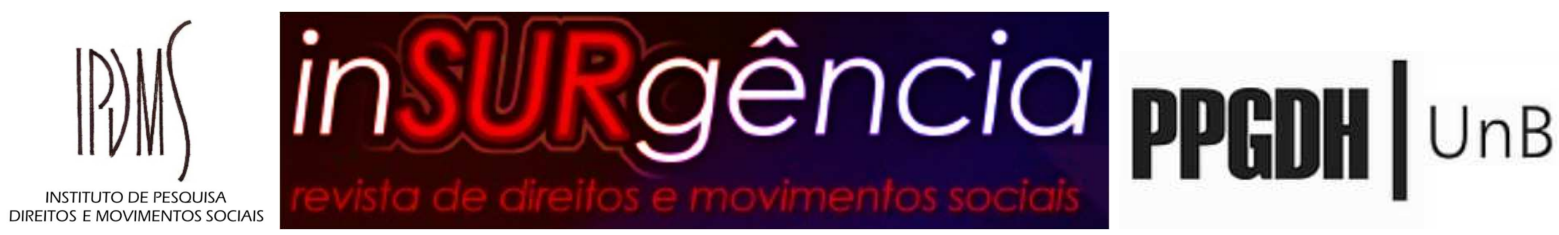

[O]s dados levantados para o Tribunal Internacional de Despejos no Brasil - TID apontaram 39 casos de conflitos que envolveram 230 mil pessoas. Importante destacar que os dados para o TID foram coletados a partir de uma chamada pública, ocorrida entre outubro e dezembro de 2018. Paralelamente outros levantamentos ocorreram no país, sendo destacados aqui os casos de Porto Alegre (RS), Curitiba (PR), São Paulo (SP), Rio de Janeiro (RJ), Recife (PE) e Fortaleza (CE).

Pois a missão em Defesa da Moradia Digna nas Ocupações Urbanas na cidade de São Leopoldo (RS) teve como objetivo a visita às Ocupações Urbanas na cidade que se encontram em estado de vulnerabilidade social e lutando pelo seu legítimo direito à moradia digna. Todas as ocupações urbanas visitadas pela missão estavam ameaçadas de despejo por força de ações judiciais que tramitavam no Foro da Comarca de São Leopoldo (RS), com exceção da Ocupação Cerâmica Anita, que estava em fase de regularização fundiária junto ao Município de São Leopoldo (ESTADO DO RIO GRANDE DO SUL, 2019).

A realidade das ocupações diz respeito à ausência total de serviços públicos e à vulnerabilidade social das famílias moradoras das ocupações. Em algumas comunidades, como é o caso da Ocupação Steigleder, faltam os serviços mais essenciais como o acesso à água potável, energia elétrica, assistência social, saúde, moradia e educação. Nessa ocupação vivem ao todo 211 famílias, que estão localizadas na beira do Rio dos Sinos, sujeitas a enchentes e alagamentos e vivem em estado extremo de pobreza, tendo que caminhar enormes distâncias para conseguir água, sem acesso à energia elétrica e, por consequência, não conseguem nem ao menos usar um refrigerador. A média de renda está ao redor de $\mathrm{R} \$ 300,00$ mensais, sendo que a maioria dos moradores (90\%) trabalham com a reciclagem de materiais. Uma parte ainda considerável das famílias era beneficiária do bolsa família e foi descadastrada pelo programa sem qualquer tipo de justificativa. Outro problema grave que afeta a comunidade é a falta de comprovante de endereço, o que impede de serem cadastrados pelos poderes públicos e terem direito a políticas públicas.

A área ocupada pertence a um particular, que ajuizou ação de reintegração de posse sobre a área e obteve o pedido de reintegração em tutela antecipada. Em fevereiro de 2017, as famílias foram notificadas pelo Oficial de Justiça de que deveriam sair do local. Nesse momento, a comunidade ameaçada de despejo se articulou e pressionou o Fórum e a Prefeitura Municipal contra o despejo, quando foi sido firmado um acordo judicial entre as partes que prevê: a suspensão do despejo, a compra da terra e a construção das moradias pela via do Programa Minha Casa Minha Vida. Foi, então, realizada mediação pelo Centro Judiciário de Solução de Conflitos e Cidadania (CEJUSC) do Fórum de São Leopoldo, onde ficou acertado que o 


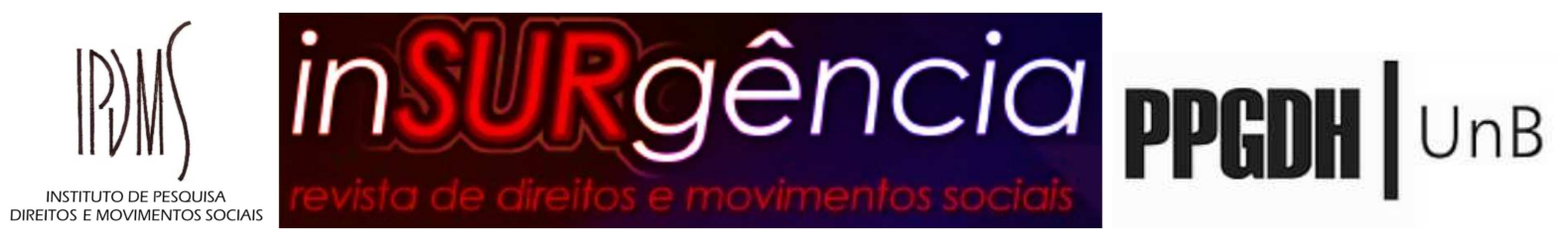

Município encaminharia a seleção das famílias para o programa e realizaria os projetos urbanísticos da área. No entanto, as informações recebidas de Brasília sobre o programa Minha Casa Minha Vida dão conta de que não há recursos mais para o programa ${ }^{3}$.

O desastre da política habitacional por que passa o Brasil foi um dado importante da missão, uma vez que afetou em cheio as ocupações que estavam em processo de mediação avançada com o proprietário, mas que não conseguiram se concretizar por falta de sustentabilidade nos programas federais que não existem mais. Outra comunidade que sofreu com essa situação é Ocupação Vitória, composta por 245 famílias e com posse de 7 anos sobre a área. Essa Ocupação tem no seu entorno uma forte infraestrutura pública de arruamento, serviços educacionais e posto de saúde, além de outros empreendimentos de interesse social como o Programa de Subsídio a Habitação de Interesse Social (PSH), do governo federal, o reassentamento de famílias para a obra do sistema ferroviário urbano (TRENSURB) e a construção das cooperativas habitacionais, porém não há acesso à água e à energia elétrica.

A área é particular e identificada por três matrículas distintas, e está judicializada em ação de reintegração de posse em que se pede o despejo das famílias ocupantes. Esse processo judicial está em mediação no CEJUSC do Fórum de São Leopoldo, para composição dos interesses entre as partes e o Município de São Leopoldo. Este, por sua vez, tenta incluir as famílias no programa Minha Casa, Minha Vida na modalidade entidades, em processo no qual já houve seleção, porém permanece sem a disponibilização de recursos para pagamento da área ao proprietário e para a construção das moradias. Todos os projetos urbanísticos já foram aprovados pelo Município, de acordo com o que oralmente informa a Secretaria Municipal de Habitação da cidade, estando pendente ainda a liberação pelo antigo Ministério das Cidades do governo federal - atual Ministério do Desenvolvimento Regional. A área tem decreto de área especial de interesse social (AEIS).

$\mathrm{Na}$ contramão das outras ocupações que passam por necessidades urgentes e enfrentam grande degradação humana está a Ocupação Cerâmica Anita, exemplo de como é possível garantir acesso à moradia digna combinando esforços públicos e dos moradores. A área é pública e ocupada por aproximadamente 25 famílias, e teve ação de reintegração de posse ajuizada pelo Município. Os moradores se articularam e resistiram à ordem de remoção, tendo

\footnotetext{
${ }^{3}$ Leia-se a matéria jornalística publicada pela Câmara dos Deputados, em 24 de setembro de 2019, que atesta que a falta de recursos prejudica o Programa Minha Casa, Minha Vida, conforme técnicos. A mesma matéria informa que a Proposta de Lei Orçamentária (PLOA) de 2020, encaminhada pelo governo para o Congresso Nacional, prevê a redução de $41 \%$ nas verbas do Programa Minha Casa, Minha Vida, o que significa um corte de 1,9 bilhão de reais. (CÂAMARA DOS DEPUTADOS, 2019).
} 


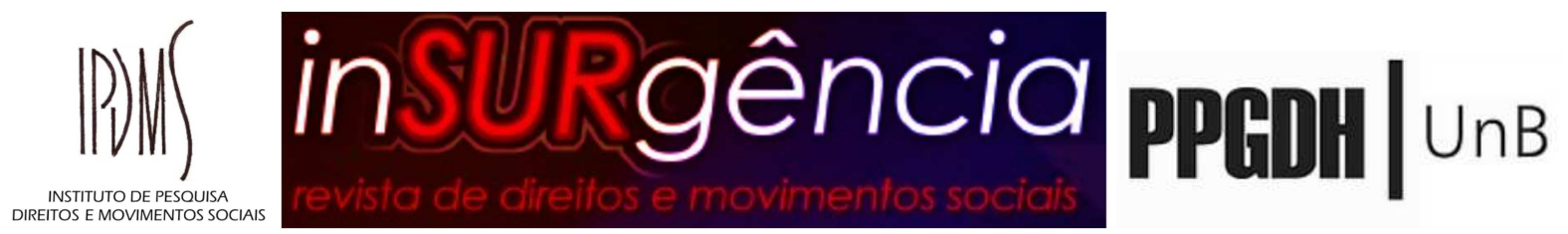

ocorrido intermediação no Fórum junto à Juíza por uma Comissão de Vereadores da cidade. O processo de mediação teve a duração de 1 ano e 4 meses, sendo que o poder público não tinha interesse em fazer qualquer acordo com as famílias, que sequer eram recebidas, e, ao final de 2016, postulou o despejo das famílias por meio da ação de reintegração de posse.

A partir da troca do governo municipal, em 2017, foi possível reiniciar as discussões no âmbito do CEJUSC. Mediante a suspensão da reintegração de posse, foi reiniciada a mesa de negociações com a desafetação da área onde seria uma praça e destinação para moradia das famílias, com a aprovação de decreto de área especial de interesse social no local da Ocupação. Os projetos urbanísticos foram aprovados pelo Município e contemplam 68 moradias no local, sendo que na Conferência de Habitação de 2017 foi aprovada Resolução para se realizar a regularização fundiária da comunidade.

$\mathrm{Na}$ área, ainda foi realizado um projeto do Instituto dos Arquitetos do Brasil/Conselho de Arquitetura e Urbanismo do Rio Grande do Sul (IAB/CAU RS), que elaborou o projeto de construção de 40 casas da Ocupação Cerâmica Anita, porém não há recursos para a construção de nenhuma casa no local. Está pendente, ainda, a regularização fundiária com o trâmite da REURB (Lei $n^{\circ}$. 13.465/2017) ${ }^{4}$, no Registro de Imóveis da cidade.

No outro extremo dessa realidade se encontra a Ocupação Justo. A Justo está assentada numa área de 34 hectares, onde moram aproximadamente 2.500 famílias há quase 20 anos. É uma área particular de propriedade da família Justo, sendo que parte da área é de propriedade pública municipal em virtude de desapropriação. Essa parte pública não está sob ameaça de despejo atualmente. Contudo, as demais famílias estão na iminência de remoção por conta de um processo judicial em andamento no Fórum da cidade. O estágio atual do processo é o de mediação no CEJUSC, que está tentando aproximação das partes para um acordo, com o apoio do Poder Executivo municipal na sua formatação. Um dos entraves para a realização de um

\footnotetext{
${ }^{4}$ A Lei $n^{\circ} .13 .465 / 2017$ (BRASIL, 2017) opera sob duas modalidades: Reurb-S, de interesse social, aplicável aos núcleos ocupados predominantemente por população de baixa renda e assim declarados em ato do Poder Executivo municipal, e Reurb-E, aplicável aos núcleos urbanos ocupados por população com outra qualificação, como é o caso de ocupações de propriedades privadas. Tanto os beneficiários quanto o Estado (Ministério Público, Defensoria Pública, Administração Pública direta e indireta) e até mesmo os proprietários privados podem requerer a Reurb e há uma série de instrumentos jurídicos que podem ser utilizados na sua aplicação. A legitimação fundiária, a compra e venda, a doação, a usucapião, a desapropriação por interesse social ou em favor dos possuidores, o direito de preempção, a concessão de uso especial para fins de moradia, a concessão de direito real de uso, são exemplos de instrumentos jurídicos que podem ser destinados à consolidação da regularização fundiária nos termos da Lei, o que explica que o papel do Estado exige uma postura ativa que regularize as ocupações urbanas da melhor forma possível aos moradores.
} 


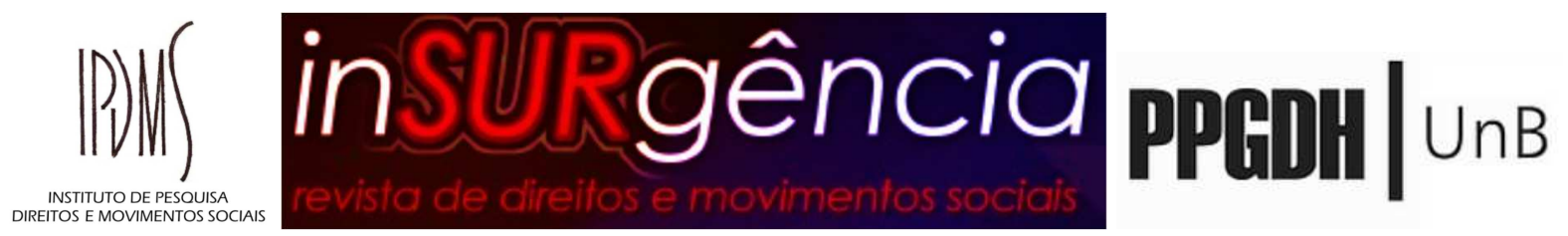

eventual acordo seria o valor pleiteado pelo proprietário da área. Segundo moradores da Ocupação Justo, a área estaria avaliada em valor próximo a 50 milhões de reais.

A Ocupação Justo conta com infraestrutura de água e energia elétrica, arruamento ou esgoto pluvial, sendo que os seus moradores têm renda variável. A Ocupação Justo chama a atenção por conta da quantidade de famílias residentes no local e da potencial tragédia imbricada na ocorrência de um despejo dos moradores.

\section{Problematização a partir do descumprimento da função social da propriedade}

A falta de regularização da terra e da moradia é um dos principais aspectos ao processo de urbanização brasileiro, em que milhares de pessoas só têm acesso ao solo urbano e à moradia através de mecanismos informais e ilegais (ALFONSIN; SERPA; FERNANDES et. al., 2002, p. 12), o que gera graves consequências socioeconômicas, urbanísticas e ambientais, uma vez que 'além de afetar diretamente os moradores dos assentamentos informais, a irregularidade produz um grande impacto negativo sobre as cidades e sobre a população urbana como um todo'. (ALFONSIN; SERPA; FERNANDES et. al., 2002, p. 12, grifo nosso). A ocupação regular e adequada não é viabilizada pelo poder público aos cidadãos, como enfatiza Edésio Fernandes:

\footnotetext{
[O]s assentamentos informais - e a consequente falta de segurança da posse, vulnerabilidade política e baixa qualidade de vida para os ocupantes - resultam do padrão excludente dos processos de desenvolvimento, planejamento, legislação e gestão das áreas urbanas. Mercados de terras especulativos, sistemas políticos clientelistas e regimes jurídicos elitistas não têm oferecido condições suficientes e adequadas de acesso à terra urbana e à moradia para os pobres, provocando assim a ocupação irregular e inadequada. (ALFONSIN; SERPA; FERNANDES et. al., 2002, p. 12).
}

Essa situação, cada vez mais evidente e preocupante na política e no cenário socioeconômico brasileiro, ocorre paralelamente às previsões legais e institucionais sobre a função social da propriedade no Brasil. A Constituição Federal, no artigo $5^{\circ}$, inciso XXIII, dispõe que a propriedade atenderá à função social, o que significa que há uma legitimação da própria lei à limitação imposta ao direito individual de propriedade privada, pautada na supremacia do interesse público sobre o interesse particular. (MANIGLIA; DOSSO, 2013). Como aponta Elisabete Maniglia (2000, p. 67), a função social da propriedade está consagrada na legislação brasileira, a fim de resolver a questão social e alcançar uma forma de organização 


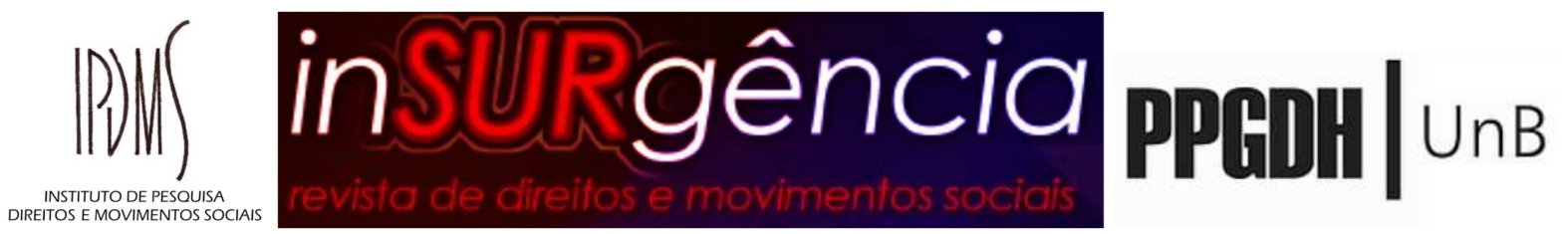

jurídico-institucional que permita solucionar algumas das tantas contradições econômicas e sociais.

Além disso, o princípio da função social da propriedade vem demarcado no Estatuto da Cidade (Lei $n^{\circ}$. 10.57/2001), nos artigos $1^{\circ}$ a 39, colocando o direito individual da propriedade em prol do bem coletivo. $\mathrm{O}$ artigo $2^{\circ}$ do Estatuto da Cidade também desponta em termos de progresso jurídico ao ordenar o pleno desenvolvimento das funções sociais da cidade e da propriedade urbana (art. $\left.2^{\circ}, I\right)$. Assim, em consonância ao direito à moradia e aos demais direitos sociais previstos no artigo $6^{\circ}$ da Constituição Federal, é possível interpretar que há uma clara distinção legal entre o direito à terra e o direito de propriedade da terra. (ALFONSIN, 2003, p. 77).

A normatividade acerca da função social da propriedade é uma luta histórica que demarca a luta por uma cidade mais justa e equânime, que tenha saneamento, habitação e dignidade acessíveis a todos. Nascido no movimento constituinte, o Movimento Nacional pela Reforma Urbana realizou em outubro de 1988 o primeiro encontro do Fórum Nacional de Reforma Urbana, que passava, assim, a ser o principal sujeito coletivo a postular a normatização do direito à cidade; criava-se o que Ermínia Maricato chama de Nova Escola de Urbanismo ${ }^{5}$ e o movimento pela Reforma Urbana avançava na conquista de importantes marcos institucionais $^{6}$. Do primeiro encontro do Fórum Nacional pela Reforma Urbana, extraem-se os três princípios básicos da política urbana, quais sejam: a) direito à cidade e à cidadania; b) gestão democrática da cidade, e; c) função social da cidade e da propriedade (ALFONSIN, 2016, p. 121). Treze anos depois do reconhecimento constitucional e da instituição do Fórum Nacional de Reforma Urbana, os artigos 182 e 183 da Constituição Federal foram regulamentados no Estatuto da Cidade, Lei nº 10.257 de 10 de julho de 2001 (BRASIL, 2001).

\footnotetext{
5 “"...] durante as décadas de 1980 e 1990, pesquisadores, professores universitários e profissionais de diversas áreas, socialmente engajados, criaram o que podemos chamar de Nova Escola de Urbanismo. Se antes esses agentes eram críticos do Estado e das políticas públicas, a partir da conquista das novas prefeituras e com o crescimento dos partidos de esquerda, notadamente do PT, eles foram se apropriando de parcelas do aparelho de Estado nos Executivos, nos parlamentos e, com menos importância, até mesmo do Judiciário. Novos programas, novas práticas, novas leis, novos projetos, novos procedimentos, sempre com participação social, permitiram o desenvolvimento também de quadros técnicos e de know-how sobre como perseguir maior qualidade e justiça urbana. As travas da macroeconomia estavam colocadas como obstáculos a serem resolvidos no futuro.". (MARICATO, 2013, p. 34).

${ }^{6}$ Além das leis decorrentes da Constituição Federal no tocante à política urbana, foi desenvolvido um conjunto de leis voltadas a consolidar a justiça urbana, destacando-se o Estatuto da Cidade, além de um conjunto de entidades políticas, como o Ministério das Cidades (2003) e as secretarias nacionais de habitação, mobilidade urbana e saneamento ambiental, e da consolidação de espaços dirigidos à participação direta de lideranças sindicais e profissionais acadêmicos e populares, como as Conferências Nacionais das Cidades [2003, 2005, 2007] e o Conselho Nacional das Cidades [2004]. (MARICATO, 2013, p. 35, grifo nosso).
} 


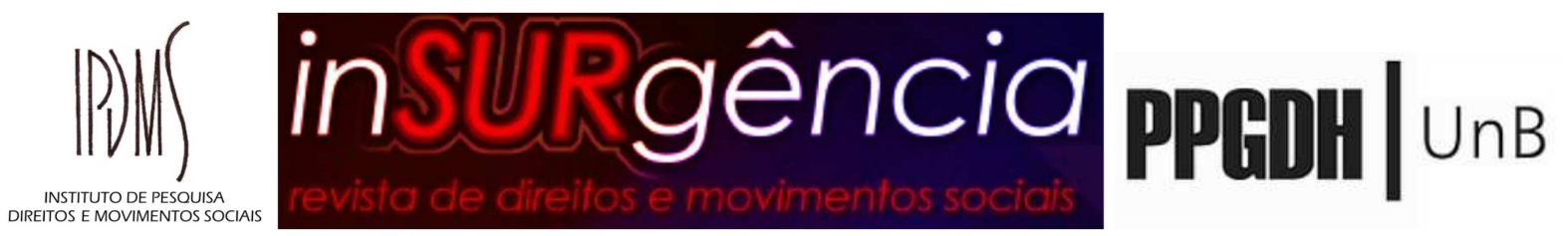

Sua publicação ocorreu onze anos após o protocolo do respectivo projeto de lei, e as razões para a longa tramitação articulam-se entre si:

(i) a década de 90 foi o período das reformas liberais no país, com ênfase para as reformas administrativas e previdenciária que redundaram em diversas emendas constitucionais que absorveram inteiramente o Congresso Nacional naquele momento, e (ii) o conteúdo do projeto de lei do Estatuto da Cidade, inteiramente comprometido com os princípios da função social da propriedade e da cidade, não harmonizava com as ideias que hegemonizavam o debate político da época, encontrando enorme resistência de muitos parlamentares que compunham o Congresso Nacional naquelas legislaturas. (ALFONSIN, 2018, p. 122).

O interesse social da propriedade urbana foi um dos eixos determinantes do Movimento Nacional pela Reforma Urbana, e articulava o princípio da função social da propriedade privada ao princípio do estado de necessidade. (SAULE JÚNIOR, 1997, p. 26). O princípio da função social da propriedade urbana seria balizador de ações do Poder Público nos conflitos sociais relacionados ao uso de áreas urbanas públicas e privadas por grupos e comunidades carentes de moradia. Também deveria ser um princípio estruturante a coibir abusos do mercado imobiliário, que crescia com a especulação sobre os chamados vazios urbanos $^{7}$ na mesma proporção em que crescia a crise habitacional no país - condições cada vez mais precárias e inseguras de moradia e déficit habitacional em quase dez milhões de unidades habitacionais, além da desestruturação do Sistema Financeiro de Habitação, com a extinção do Banco Nacional de Habitação. (SAULE JÚNIOR, 1997, p. 28).

Na legislação urbanística, há uma ampla preocupação com a gestão compartilhada do solo urbano e com a ordenação e controle do uso do solo, de modo a evitar que os lugares da cidade sejam construídos conforme interesses escusos da população. As diretrizes gerais da política urbana, expressas no extenso artigo $2^{\circ}$ do Estatuto da Cidade, buscam evitar, essencialmente, a utilização inadequada dos imóveis urbanos, a proximidade de usos incompatíveis ou inconvenientes, o parcelamento do solo, a edificação ou o estabelecimento de usos excessivos ou inadequados à infraestrutura urbana, a instalação de empreendimentos ou atividades que possam comprometer o tráfego das cidades sem que haja previsão de

\footnotetext{
${ }^{7}$ Vazios urbanos são áreas privadas vazias, desocupadas propositadamente por seus proprietários, enquanto estes aguardam a valorização imobiliária decorrente dos investimentos públicos realizados nas regiões em que estas propriedades estão localizadas. Nas palavras de Betânia Alfonsin (2000, p. 155): “[...] A dinâmica é bem conhecida: a terra, tornada mercadoria no regime capitalista, é comprada barata já que desprovida de infraestrutura. O proprietário, que trata o espaço urbano como 'investimento' deixa a terra ociosa e espera que, ao longo dos anos, a provisão de serviços e equipamentos públicos dote a gleba de infraestrutura e com isto o terreno passe a valer bem mais do que o valor originalmente pago pelo mesmo".
} 


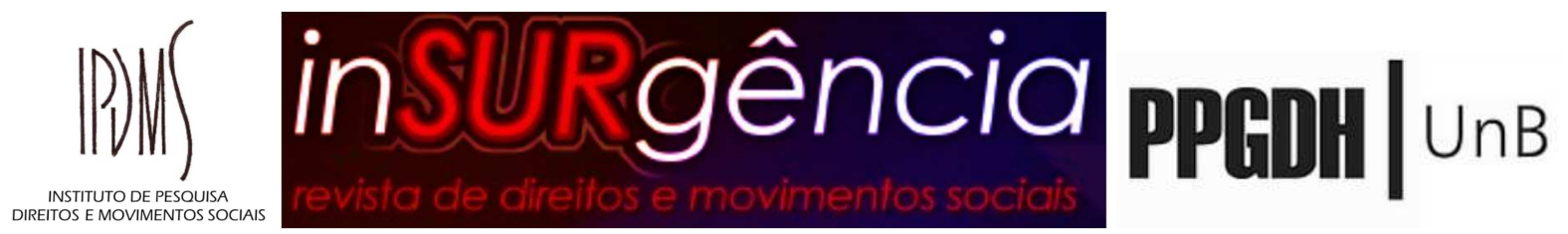

infraestrutura correspondente, a retenção especulativa de imóvel urbano que resulte na sua subutilização ou inutilização, a deterioração de áreas urbanizadas e a degradação ambiental. (LEAL, 2003, p. 96-97).

Esses instrumentos são destinados ao cumprimento da função social da propriedade urbana, uma vez que consagram a limitação do direito privado de propriedade ao definirem o potencial construtivo dos terrenos, sujeitam áreas vazias ou subutilizadas localizadas em áreas de infraestrutura ${ }^{8}$ ao pagamento de IPTU progressivo no tempo e à edificação e parcelamento compulsórios, conforme a destinação específica determinada pelo Plano Diretor de cada cidade. (ROLNIK, 2001, p. 5). Surgem como meio de interação entre a regulação urbana e a lógica de formação de preços no mercado imobiliário e potencializam o enfrentamento da expansão horizontal ilimitada e do triunfo do mercado imobiliário gerador de capital especulativo que, nas palavras de Raquel Rolnik (2001, p. 5), “caracterizam nosso urbanismo selvagem e de alto risco". Revelavam-se destinados a enfrentar as engrenagens de formação de preços e negócios no mercado imobiliário.

O fortalecimento institucional possibilitado aos municípios pela Constituição e pelo Estatuto da Cidade teve sempre como barreira normativa a tradição civilista na definição do direito de propriedade ${ }^{9}$, além do imaginário de que a produção da ordem jurídica se dá no monopólio do Estado (FERNANDES, 2006, p. 9). Se entre os anos 1960 e os anos 1980, o Brasil experimentou uma mudança significativa na composição da cidade e do campo, com grandes movimentos migratórios em direção às grandes cidades ${ }^{10}$, a composição social dessas cidades foi segregando progressivamente - sem se esquecer o papel determinante da raça na segregação social - e os processos decisórios e de gestão urbana foram se concentrando nos grupos econômicos dominantes, de modo que a "a ordem pública nas cidades latino-americanas foi reduzida a uma ordem estatal pouco democrática, quando não autoritária". (FERNANDES, 2006, p. 9, grifo nosso). Nesse contexto de rápido crescimento urbano em contraposição à tradição da propriedade privada individual exclusiva e registrada, as cidades brasileiras que experimentaram alguma intervenção estatal por meio de planos diretores, zoneamentos e leis

\footnotetext{
${ }^{8}$ Áreas de infraestrutura são as que contêm, principalmente, pavimentação, saneamento, iluminação, transporte.

${ }^{9}$ O Código Civil prevê, no seu artigo 1.228: "O proprietário tem a faculdade de usar, gozar e dispor da coisa, e o direito de reavê-la do poder de quem quer que injustamente a possua ou detenha." (BRASIL, 2002). Adiante, no artigo 1.231, determina que "a propriedade presume-se plena e exclusiva, até prova em contrário". (BRASIL, 2002).

${ }^{10} \mathrm{Na}$ década de 1960, o Brasil tinha 44,67\% da população nas cidades, segundo o levantamento censitário da época; em 1980, 67,59\% da população era urbana e houve um acréscimo de 50 milhões de pessoas nas cidades. (MARICATO, 2013, p. 30).
} 


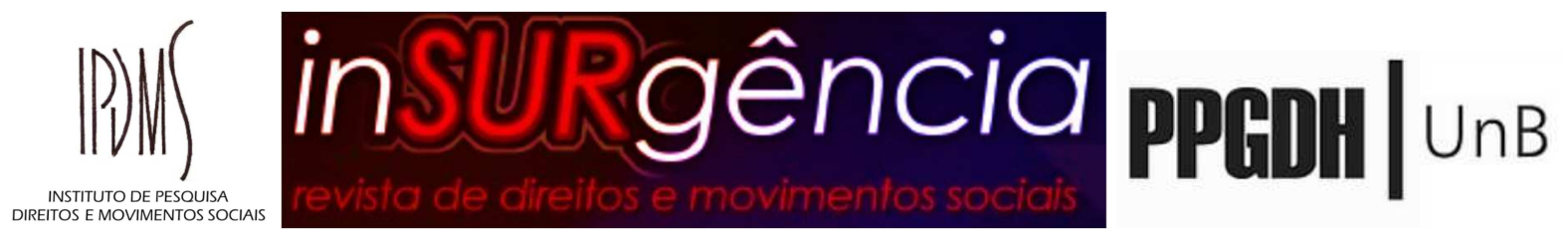

urbanísticas viram o desenvolvimento de uma tradição urbanística de planejamento tecnocrático, efetuado conforme normas que, além de distantes das realidades sócioeconômicas de acesso ao solo urbano e à moradia nas cidades, eram fiscalizadas e implementadas por órgãos públicos locais descapacitados. (FERNANDES, 2006, p. 9).

Esse cenário político torna acirrada a disputa pelo acesso aos investimentos em urbanização: a cidade reserva os seus melhores lugares mediante suas leis de zoneamento, das suas políticas urbanas, para a produção da cidade das classes médias e de seus bairros aprioristicamente urbanizados com equipamentos de infraestrutura; paralelamente, o restante da cidade foi construído de forma espontânea e informal (ROLNIK, 2015, p. 181). A exclusão urbanística se dá no âmago da ambiguidade jurídica que caracteriza as diversas formas de ocupação da cidade, um conjunto de "territórios de definições cambiantes entre legal e ilegal, construídos a partir de pressões, mediações políticas e camadas de legalidades" (ROLNIK, 2015, p. 173).

Nesse sentido, a produção do espaço urbano no Brasil é marcada por um planejamento urbano excludente e seletivo, que estimula a informalidade e a ilegalidade [uma vez que o mercado imobiliário que produz a cidade legal é restrito e direcionado aos lugares da cidade que podem ter seus altos custos de infraestrutura arcados pelos consumidores desse mesmo mercado]. Como exemplo disso, temos o contraste entre os bairros residenciais exclusivos e seus chamarizes urbanísticos em torno da infraestrutura preestabelecida, e os bairros populares [predominantes nas cidades brasileiras], construídos espontaneamente e sem condições de infraestrutura básica - água encanada, rede de esgotos, iluminação pública, eletricidade, limpeza, pavimentação e drenagem podem demorar até décadas para serem instalados pelos serviços públicos municipais (ROLNIK, 2003, p. 131). A esse urbanismo [planejamento e regulação urbanística] que concentra qualidades urbanísticas em locais acessíveis por uma minoria da população, a quem se destinam legislação, contratos, financiamentos imobiliários, créditos e titulação da propriedade, enquanto às maiorias restam as terras vetadas para a construção ou para o mercado formal, que acabam se tornando espaços precários e periféricos ${ }^{11}$,

\footnotetext{
${ }^{11}$ A formação das periferias urbanas é bem contextualizada por James Holston (2013, p. 197, grifo nosso): “As periferias urbanas se desenvolveram no Brasil como o lugar dos trabalhadores pobres e o lugar para os trabalhadores pobres. Depois dos anos 1930, essas regiões afastadas se tornaram praticamente as únicas áreas em que os trabalhadores estabelecidos e os novos imigrantes conseguiam garantir uma residência na economia urbana de um Brasil que se industrializava. E fizeram-no construindo barracos numa subdivisão periférica que quase sempre era ilegal e não dispunha da maioria dos serviços de infraestrutura. Quando a migração urbana se acelerou nas décadas subsequentes, o mesmo aconteceu com essas autoconstruções em regiões afastadas, fora do alcance da supervisão do governo ou de seus funcionários. Ao mesmo tempo, um novo Estado nacional
} 


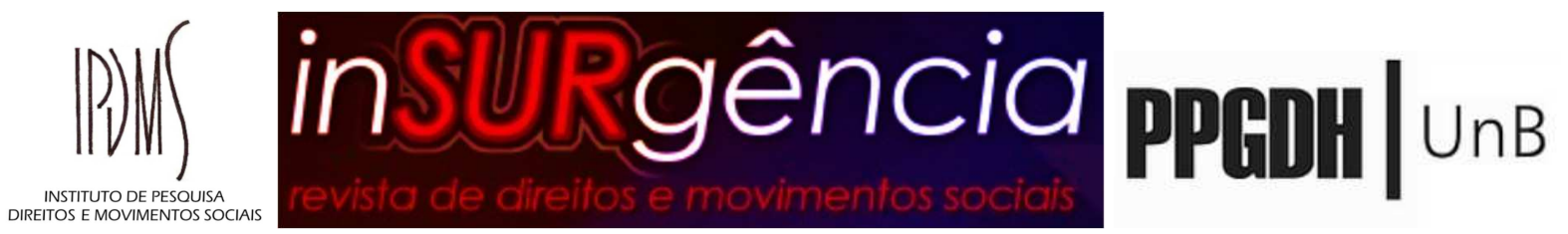

Raquel Rolnik (2008) chama de "lógica do caos": o espaço que a lei permite urbanizar é apenas aquele reservado ao circuito restrito de que possui crédito e propriedade registrada em seu nome.

Com isso, estabeleceu-se um contingente vasto de assentamentos irregulares nas cidades (ROLNIK, 2008), formando, assim, uma zona de ilegalidade habitacional em paralelo à ordem urbana. Raquel Rolnik (1999) chama atenção, nesse sentido, para o paradigma políticocultural em que atua a legislação urbanística, que organiza e classifica territórios urbanos de acordo com o "funcionamento concreto dos mercados imobiliários que atuam na cidade" (ROLNIK, 1999). A noção de cidade, nesse contexto, é eminentemente jurídica e política, considerando o poder e à discricionariedade atribuídos à lei pelo Estado na definição da política urbana - cada município define a organização espacial de sua administração conforme sua lei orgânica e o seu plano diretor (HOLSTON, 2013, p. 202). A distribuição espacial, amparada pela lei e pelas administrações políticas, é fundamentalmente desigual.

Esse cenário de desigualdade é determinado pela própria configuração espacial constituída para a circulação do capital. David Harvey explica os fundamentos dessa configuração e o papel de cada ator nela envolvido:

\begin{abstract}
[a]s necessidades peculiares da circulação do capital nos ambientes construídos têm significado a evolução de um tipo especial de sistema de produção e realização que define novos papéis para os agentes econômicos. Os proprietários de terra recebem renda, os empresários recebem aumentos na renda baseados nas melhorias, os construtores ganham o lucro do empreendimento, os financistas proporcional capital monetário em troca dos juros, ao mesmo tempo que podem capitalizar qualquer forma de receita acumulada pelo uso do ambiente construído em um capital fictício [preço da propriedade] e o Estado pode usar os impostos [atuais ou antecipados] como suporte para investimentos que o capital não pode ou não vai realizar, mas que não obstante expande a base para a circulação local do capital. Esses papéis existem, não importa quem os desempenha. Quando os capitalistas compram terra, viabilizam-na e constroem sobre ela usando seu próprio dinheiro; então eles assumem papeis múltiplos. Mas quanto mais capital eles adiantam nesse tipo de atividade, menos eles terão para investir diretamente na produção. Por essa razão, a produção e a manutenção dos ambientes construídos com frequência se cristalizam em um sistema extremamente especializado, vinculando os agentes econômicos que desempenham cada papel separadamente ou em combinações limitadas. (HARVEY, 2013, p. 503, grifos do autor).
\end{abstract}

A apropriação da propriedade privada da terra pelo mercado para extração de renda fundiária tem uma dimensão política essencial que remanesce às premissas liberalistas que têm

procurava modernizar a organização da economia e da sociedade que se urbanizavam seu objetivo era articular uma nova esfera pública de cidadania para canalizar e regulamentar essa nova força de trabalho humana. [...] Assim, a segregação espacial e a diferenciada cidadania foram processos simultâneos num projeto de modernização nacional. [...]”. 


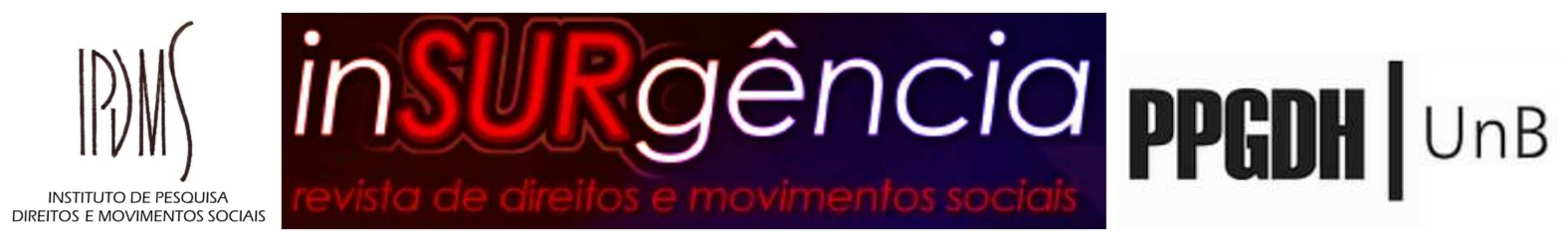

na acepção de propriedade um direito natural e imanente à personalidade, justificando-se, assim, a apropriação da terra. Ser proprietário é, nessa lógica, sinônimo de ser sujeito e de ser livre. Nas palavras de James Holston (2013, p. 159, grifo nosso), a propriedade é "a corporificação e a exteriorização do livre-arbítrio de um indivíduo. Assim, um indivíduo é livre à medida que for proprietário de sua própria pessoa, uma relação corporificada e expressa na propriedade de terra e de coisas. [...]”. De maneira que a liberdade é uma função da propriedade, um governo responsável pela liberdade de seu povo deve priorizar a garantia da propriedade. (HOLSTON, 2013, p. 159).

\section{O papel do sistema de justiça na proteção das populações vulneráveis que demandam proteção do Estado}

As situações de vulnerabilidade social das pessoas que moram nas ocupações urbanas da cidade de São Leopoldo (RS), caracterizadas pela falta completa de condições mínimas de habitabilidade e pela constante insegurança na posse desses coletivos, levam à conclusão de que a dignidade humana dessas pessoas está relegada a um segundo plano. Não é aceitável que um contingente imenso de pessoas viva sem acesso à água potável nos dias de hoje. A realidade da Ocupação Steigleder é muito dura nesse sentido já que os moradores são obrigados a caminharem uma considerável distância porque não chega água nas suas casas. A missão constatou que moradores não conseguem ligar o refrigerador para conservar os alimentos, o que é um absurdo.

Outra situação de vulnerabilidade é no tocante ao processo de "descadastramento" de pessoas do programa Bolsa Família. Importante observar que as famílias recebiam o benefício porque cumpriam os requisitos legais para tanto e de uma hora para outra passaram a não cumpri-los mais. Ao procurarem explicações do Centro de Referência de Assistência Social (CRAS) local, são informados que nada podem fazer porque estão numa área "invadida" e que sem endereço formal não existe possibilidade de garantir a revisão do benefício. $O$ tema da desqualificação da cidadania dos moradores das Ocupações foi recorrente em todas as Ocupações visitadas, quando o poder público nega serviços públicos por força das pessoas não estarem vinculadas a um endereço formal na cidade.

Da mesma forma ocorre quanto à insegurança na posse. Todas as ocupações estão inseguras na sua posse, isto é, ameaçadas de despejo. A exceção se encontra na Ocupação 


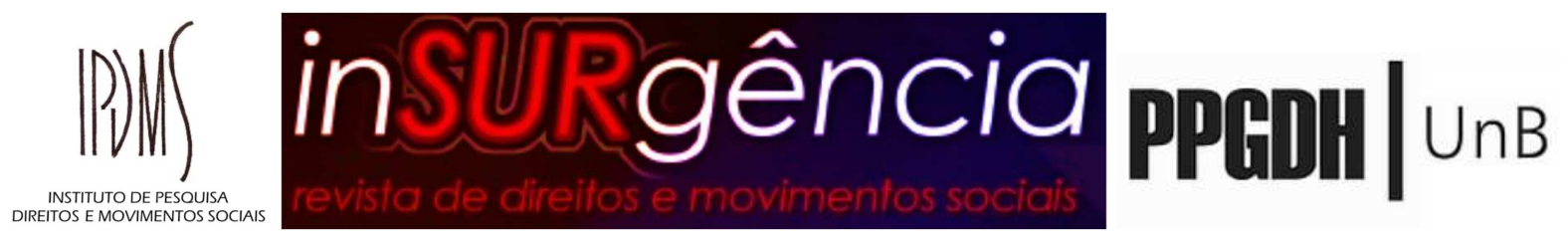

Cerâmica Anita, onde existe um trabalho conjunto com a Secretaria Municipal de Habitação em que se prevê a regularização fundiária dos moradores com a titulação, mas que ainda não foi finalizado. Todas as demais áreas, portanto, estão ameaçadas de despejo, que ainda não ocorreu porque houve certa mobilização de resistência das ocupações e de atores públicos e privados na busca de alternativas ainda não consolidadas no âmbito das mediações levadas adiante pelo CEJUSC do Fórum de São Leopoldo - que, se não chegar a bom termo, poderá levar ao despejo de milhares de pessoas de suas moradias na cidade. Lamentavelmente, segue a precarização do serviço público e a insegurança na posse em detrimento da dignidade humana dos moradores das ocupações.

O direito à propriedade já não é mais um direito absoluto e superior aos demais direitos. É dever do Estado garantir a proteção da propriedade, sem esquecer de garantir também a efetividade do direito à moradia digna, em defesa da dignidade da pessoa humana (MÜLLER, 2014). Isso é ainda mais forte quando se verifica que, no caso concreto, as ocupações visitadas pela missão são, em sua maioria, localizadas em áreas privadas da cidade que não cumpriam sua função social e que se tornaram vazios urbanos e imóveis abandonados.

No ordenamento internacional de direitos humanos, os despejos são considerados grave violação aos direitos humanos, conforme dispõem as orientações das Nações Unidas especialmente no seu Comentário Geral n 7 (Art. 3), do Comitê de Direitos Econômicos, Sociais e Culturais, que os definem como "a remoção permanente ou temporária de pessoas, famílias e/ou comunidades de suas moradias e/ou das terras que ocupam, contra a sua vontade e sem oferecer-lhes meios apropriados de proteção legal ou de outra índole nem permitir-lhes seu acesso a elas."

Isso é o que diz a ONU na Resolução no 2004/2841 do seu Conselho de Direitos Humanos:

[a] prática de despejos forçados é [considerada] contrária as leis que estão em conformidade com os padrões internacionais de direitos humanos, e constituem uma grave violação de uma ampla gama de direitos humanos, em particular o direito à moradia adequada.

A ONU reforça ainda esse entendimento no Comentário Geral $n^{\circ} 7$ do Comitê de Direitos Econômicos, Sociais e Culturais que no seu parágrafo 16 prevê que:

[o]s despejos não podem resultar na constituição de indivíduos sem casa ou vulneráveis a violações de outros direitos humanos. No caso da pessoa afetada ser incapaz de prover por si mesma uma alternativa, o Estado deve adotar todas as medidas apropriadas, ao máximo de seus recursos disponíveis, para assegurar que uma 
moradia alternativa adequada, reassentamento ou acesso à terra produtiva estejam disponíveis.

É possível verificar que, pelas normas internacionais de direitos humanos, é inconcebível a prática dos despejos, sobretudo quando esses despejos são realizados pelo próprio Estado. E mais quando esse mesmo Estado gera com sua decisão mais violações aos direitos humanos, especialmente quando se trata de milhares de famílias de pessoas sem teto nas cidades.

As ocupações urbanas visitadas no âmbito da missão estão carentes de serviços públicos e isso é uma grave violação ao direito humano internacional. O Comentário Geral $\mathrm{n}^{\mathbf{o}} 4$ do Comitê DHESC das Nações Unidas estabelece as condições necessárias para a garantia da moradia adequada, quais sejam:

\begin{abstract}
Segurança da posse: Todas as pessoas têm o direito de morar sem o medo de sofrer remoção, ameaças indevidas ou inesperadas; Disponibilidade de serviços, infraestrutura e equipamentos públicos;

Custo acessível: O custo para a aquisição ou aluguel da moradia deve ser acessível, de modo que não comprometa o orçamento familiar; Habitabilidade: A moradia adequada tem que apresentar boas condições de proteção contra frio, calor, chuva, vento, umidade entre outros; Não discriminação e priorização de grupos vulneráveis; Localização adequada: Para ser adequada, a moradia deve estar em local que ofereça oportunidades de desenvolvimento econômico, cultural e social. Adequação cultural: A forma de construir a moradia e os materiais utilizados na construção devem expressar tanto a identidade quanto a diversidade cultural dos moradores e moradoras.
\end{abstract}

Isso se torna mais claro ainda quando vemos que, em novembro de 2002, o Comitê das Nações Unidas para os Direitos Econômicos, Sociais e Culturais já havia formulado seu Comentário Geral n. ${ }^{\circ} 15$ sobre o direito à água afirmando que "o direito humano à água prevê que todos tenham água suficiente, segura, aceitável, fisicamente acessível e a preços razoáveis para usos pessoais e domésticos.

Já em 28 de julho de 2010, a Assembleia Geral das Nações Unidas, por meio da Resolução A/RES/64/292, declarou a água limpa e segura e o saneamento um direito humano essencial para gozar plenamente a vida e de todos os outros direitos humanos.

Por fim, o Pacto Internacional de Direitos Econômicos, Sociais e Culturais prevê no seu art. 11 que:

$\S 1$. Os Estados-partes no presente Pacto reconhecem o direito de toda pessoa a um nível e vida adequada para si própria e para sua família, inclusive à alimentação, vestimenta e moradia adequadas, assim como uma melhoria contínua de suas condições de vida. Os Estados-partes tomarão medidas apropriadas para assegurar a consecução desse direito, reconhecendo, nesse sentido, a importância essencial da cooperação internacional fundada no livre consentimento." 


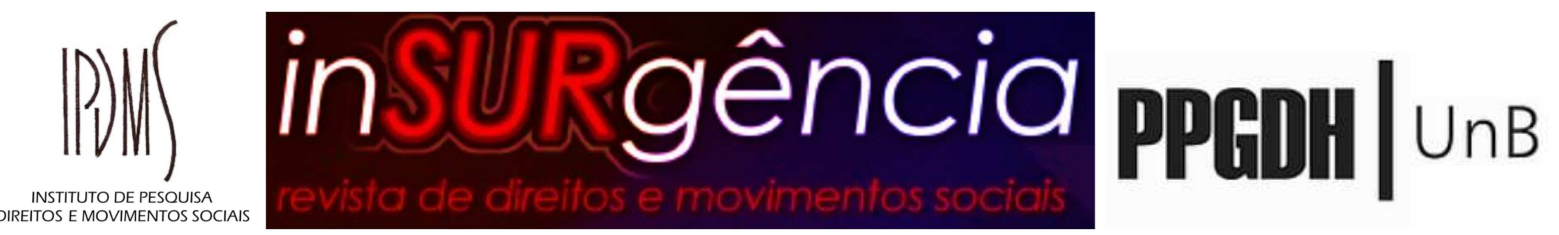

É urgente o estabelecimento de uma alternativa aos despejos e que garanta os direitos humanos tem sido uma demanda de muito tempo das organizações da sociedade civil e movimentos populares que vivem cotidianamente o problema das remoções e da falta de moradia. Recentemente, foi aprovada pelo Conselho Nacional de Direitos Humanos - CNDH a Resolução n” 10 de 17 de outubro de 2018 que dispõe "sobre soluções garantidoras de direitos humanos e medidas preventivas em situações de conflitos fundiários coletivos rurais e urbanos."

No seu artigo $1^{\circ}, \S 1^{\circ}$, a Resolução condena as práticas de despejos nos seguintes termos: "Os despejos e deslocamentos forçados de grupos que demandam proteção especial do Estado implicam violações de direitos humanos e devem ser evitados, buscando-se sempre soluções alternativas." Já no seu artigo $7^{\circ}$, estabelece uma série de medidas que o juiz deverá observar no caso de apreciação de uma ação judicial que implique em ameaça de despejo:

Art. $7^{\circ}$. Quando se tratar de conflito fundiário coletivo, primando pelos princípios da cooperação, boa fé, busca da auto composição e do atendimento aos fins sociais, bem como do resguardo da dignidade da pessoa humana, proporcionalidade, razoabilidade, legalidade, publicidade e eficiência, previstos na Constituição Federal de 1988 e no Código de Processo Civil, o/a juiz/a deverá, antes da apreciação da liminar, adotar as seguintes medidas:

I - Todos/as os/as afetados/as devem ser pessoalmente citados/as, não se admitindo citação ficta, nem mesmo sob justificativa de insegurança ou de não localização das pessoas afetadas;

II - Intimar a Defensoria Pública para o adequado exercício de sua intervenção obrigatória, independentemente da constituição de advogado pelas partes, para exercício de sua missão constitucional de promoção e defesa dos direitos humanos, na relação jurídico-processual;

III - Zelar pela obrigatória intervenção do Ministério Público nos litígios coletivos pela posse de terra rural ou urbana, sempre que não for parte, que deverá atuar no sentido de garantir o respeito aos direitos humanos dos grupos que demandam especial proteção do Estado afetados pelo conflito;

IV - Designar audiência para que o autor justifique previamente o alegado, como medida de boa prática processual e realização do princípio da cooperação e auto composição, ainda que os fatos, objeto do litígio, datem de período inferior a ano e dia;

V - Verificar se o autor da ação possessória demonstrou a função social da posse do imóvel, se comprovou o exercício da posse efetiva sobre o bem e, cumulativamente, em caso de posse decorrente de propriedade, se apresentou título válido;

VI - Considerar a dominialidade do imóvel, tanto em ações possessórias quanto em petitórias, como mecanismo necessário à garantia da correta utilização do patrimônio público fundiário e combate à grilagem e especulação imobiliária, devendo para tanto exigir a certidão de inteiro teor da cadeia dominial do imóvel desde a origem, aferindo o seu regular destacamento do patrimônio público e a regularidade jurídica e tributária dos imóveis;

VII - Avaliar o impacto social, econômico e ambiental das decisões judiciais tendo em conta a proteção de grupos em situação de vulnerabilidade, inclusive considerando o número de pessoas, grupos e famílias, com suas especificidades; 


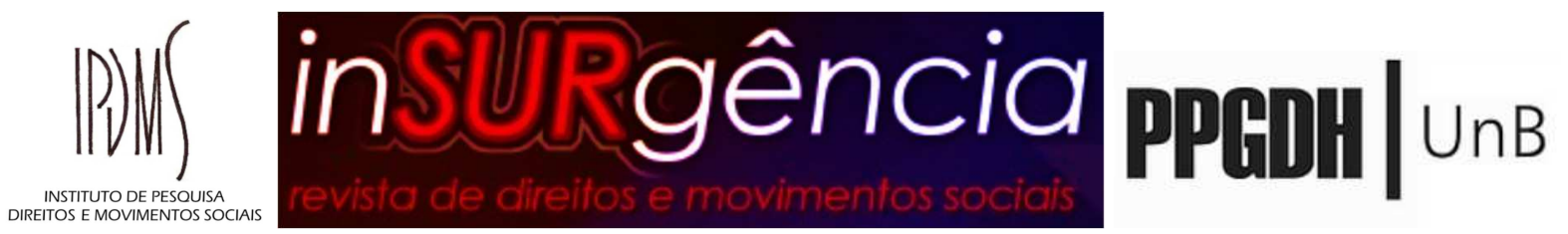

VIII - Realizar inspeção judicial tendo como premissa que tal medida em conflitos coletivos fundiários é procedimento indispensável à eficiente prestação jurisdicional nos termos do artigo 126, parágrafo único, da Constituição Federal, com a devida intimação prévia e pessoal das pessoas afetadas;

IX - Designar audiência de mediação, de acordo com o art. 565 do CPC, expedindo intimações para comparecimento do Ministério Público, Defensoria Pública e os órgãos responsáveis pela política agrária e pela política urbana da União, de Estado ou do Distrito Federal e do Município onde se situe a área objeto do litígio, devendo estes aportar propostas e informações relevantes para a solução do conflito, observado o que dispõem os artigos 378 e 380 do CPC.

Nesse sentido, o papel do Poder Judiciário se revela fundamental na salvaguarda dos direitos humanos das populações vulneráveis que demandam proteção do Estado. Por isso chama a atenção o caso de São Leopoldo (RS), onde se verifica que, nas ocupações urbanas visitadas pela missão, há, de um lado, o Poder Judiciário atuando na prestação jurisdicional ao proprietário, que demanda a retomada do seu imóvel ocupado, enquanto, de outro lado, o mesmo Poder Judiciário busca garantir também a possibilidade de mediação do conflito entre as partes e com participação de outros atores, como o Poder Executivo local, o Ministério Público Estadual e a Defensoria Pública Estadual, por exemplo, sendo que alguns casos são exitosos e outros não.

Porém, essa não é uma prática verificada em outras comarcas pelo Brasil afora onde a temática fundiária e urbanística não alcança os processos judiciais. Pesquisa realizada com base em acórdãos do Tribunal de Justiça de São Paulo identificou que:

[q]uanto à fundamentação dos acórdãos, embora o princípio da função social da propriedade urbana seja o de maior incidência, os princípios relacionados aos aspectos formais do processo judicial são predominantes se somados. Destaca-se a incidência dos princípios relacionados à celeridade processual, ao devido processo legal, à legalidade e segurança jurídica. A principal fundamentação dos acórdãos não se dá pelos princípios ou pelos dispositivos constitucionais, mas sim pela legislação infraconstitucional, com destaque para a Lei 10.257/2001 do Estatuto da Cidade (especialmente os dispositivos sobre a usucapião), para Leis Municipais e para o Código de Processo Civil; Desconhecimento por parte dos julgadores das diretrizes gerais da Política Nacional de Desenvolvimento Urbano (art. $2^{\circ}$ do Estatuto da Cidade) (LIBÓRIO et. al., 2016, p. 110)

Diante disso, assume especial relevo a necessidade de colocar em prática a Resolução $\mathrm{n}^{\circ}$ 10/2018 do Conselho Nacional dos Direitos Humanos, que trata de soluções garantidoras dos direitos humanos em conflitos fundiários urbanos e rurais. A mediação de conflitos pode ser uma dessas alternativas aos despejos, uma vez que:

[a] mediação é um instrumento que, se utilizado corretamente, constitui um meio eficiente para a solução de conflitos fundiários, já que confere o poder emancipador 


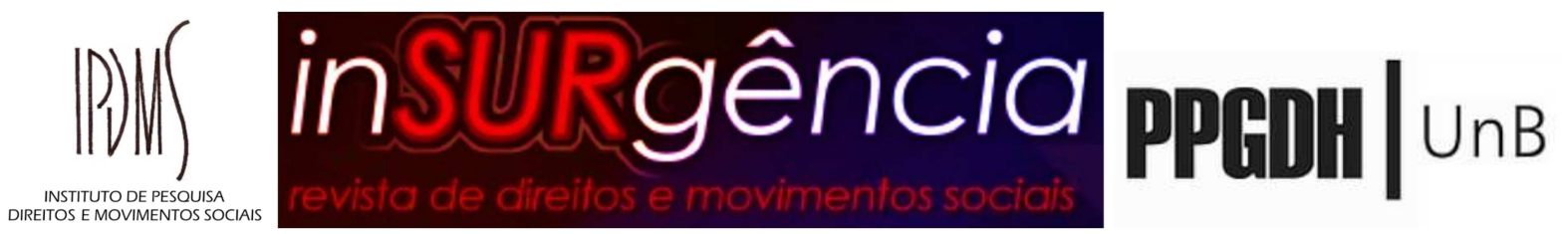

para os cidadãos em situação de conflito, além de ser uma ferramenta que auxilia na promoção da democracia, sendo uma alternativa válida para promover o debate, empoderando devidamente as partes envolvidas como sujeitos ativos de seus direitos. Além disso, por se tratar de um método não adversarial, afasta-se da lógica do "ganha-perde", tradicional do Judiciário, o que configura a mediação como um meio mais eficiente e resolução de conflitos.” (BRASIL, 2013, p. 110).

Não se trata, portanto, de escassez de leis: leis existem, e muitas. O Brasil possui uma das legislações contemporâneas mais avançadas em termos de direito à cidade, especialmente se tomarmos como referência o Estatuto da Cidade. Entretanto, nem instrumentos democráticos são capazes de deter a imposição dos interesses capitalistas: a ambiguidade que constitui a política e regulação urbanística e determina zonas de fronteira entre o legal e o ilegal, entre o público e o privado, entre o formal e o informal, é direcionada e propositada à segregação.

\section{Considerações finais}

O direito à cidade, que tem no direito à moradia sua manifestação mais evidente, é, portanto, fundamentado por três princípios fundamentais: o exercício pleno da cidadania, a gestão democrática da cidade e a função social da cidade e da propriedade urbana. Enquanto os dois primeiros têm a ver com a realização de todos os direitos humanos e fundamentais e a garantia da dignidade e do bem estar coletivo dos cidadãos equanimemente, garantindo-se o controle e a participação de todas as pessoas que moram na cidade, através de formas diretas e representativas no planejamento e governo das cidades. A função social da cidade e da propriedade urbana se referem a uma lógica inversa da que se verifica no âmbito da cidade colonial, uma vez que "os interesses e direitos coletivos devem subordinar os limites do direito individual de uso da propriedade, de forma a garantir o uso socialmente justo e ambientalmente equilibrado do espaço urbano". (ROLNIK, 2012).

O direito à moradia representa, portanto, um grande desafio aos governos em todas as esferas: municipal, estadual e federal. É necessário que se estabeleçam políticas públicas eficazes no sentido de garantir o que está na Constituição e no Estatuto da Cidade — e realizar o direito que todos têm a um nível adequado de vida, no que se inclui a moradia digna. Entretanto, o que acontece é que o salário não cobre o custo de vida nas grandes cidades, cujos lugares centrais e mais bem equipados com infraestrutura adequada estão destinados às pessoas mais endinheiradas. Resta, então, ao povo trabalhador mais pobre morar e fazer sua vida nas 


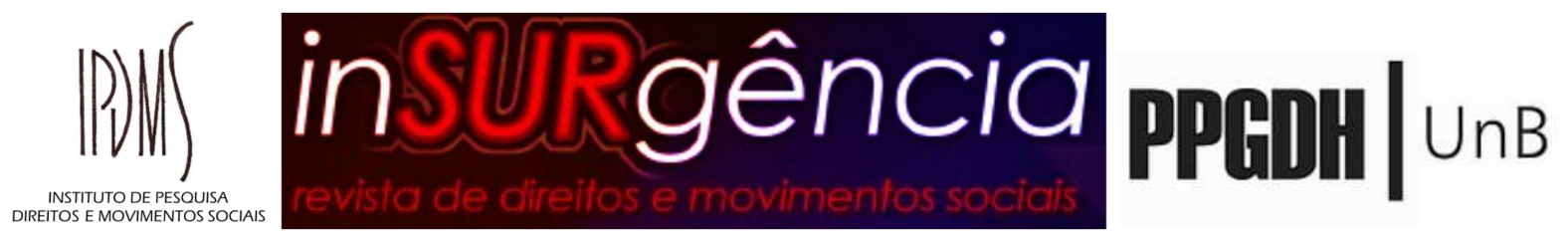

periferias, autoconstruindo sua moradia, muitas vezes de forma precária (rústica ou improvisada) e sem condições adequadas de salubridade.

Confirmando as hipóteses deste artigo, a missão realizada identificou um grave potencial de realização de despejos na cidade, tendo em vista que as ocupações visitadas em sua maioria estão com suas situações judicializadas e pendentes processos de medições que não estão terminados com garantia de moradia para as famílias e comunidades ocupantes. Da mesma forma, verificou-se que as seis áreas da rede de alta tensão vão demandar um grande esforço coletivo e institucional para que as medidas existentes não violem direitos humanos com a remoção as pessoas de suas casas.

A missão teve a oportunidade de concluir que um ponto em comum de todas as ocupações visitadas diz respeito à procura, pelo proprietário, da área ocupada do Poder Judiciário para buscar uma decisão que retire os moradores do local. Apesar de já haver decisões que determinam a retirada das pessoas na maioria das ocupações, tem havido um procedimento de mediação desses conflitos impulsionado pelo Poder Judiciário com a entrega do processo judicial para que um grupo de mediação busque uma alternativa pacífica que não seja um despejo violento, prevendo soluções também para os moradores das áreas ocupadas.

A missão identificou, ainda, a possibilidade de se fortalecer esses espaços de mediação, com o apoio técnico e especializado de núcleos de práticas e grupos de pesquisas da UNISINOS, a qual se colocou à disposição para apoiar esse trabalho e integrar um Grupo de Trabalho para se discutir como se trabalharia conjuntamente. Enfatizamos, nesse sentido, que se trata de um ótimo momento de aperfeiçoamento dos estudantes da Universidade, que farão uso das técnicas no caso concreto e real.

\section{Referências}

ALFONSIN, Betânia. Da invisibilidade à regularização fundiária: a trajetória legal da moradia de baixa renda em Porto Alegre - século XX. Porto Alegre: Programa de Pós-Graduação (Mestrado) em Planejamento Urbano e Regional da Universidade Federal do Rio Grande do Sul, 2000.

Repercussões da Nova Agenda Urbana no Direito Público e Privado no Brasil e na América Latina: o Papel do Direito à Cidade. In: BELLO, Enzo; KELLER, Rene José (Orgs.). Curso de Direito à Cidade: teoria e prática. Rio de Janeiro: Lumen Juris, 2018, p. 119-132. 


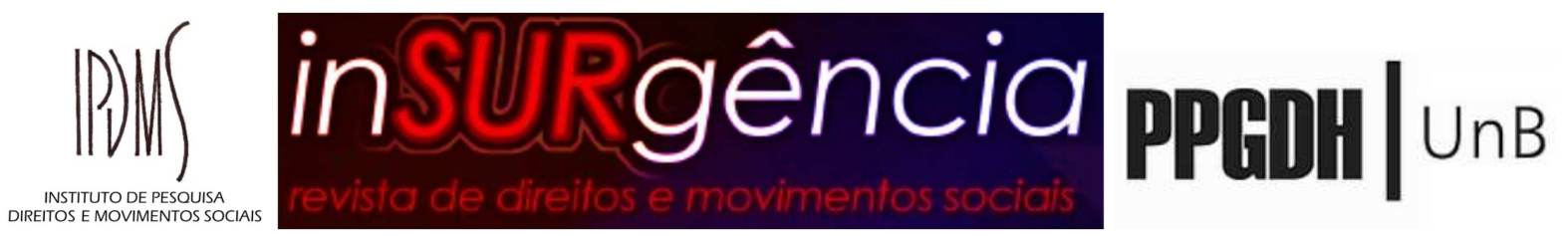

Uma copa no meio do caminho: o planejamento urbano de Porto Alegre em xeque na Copa do Mundo de 2014. In: PANIZZI, Wrana (Org.). Outra vez Porto Alegre: a cidade e seu planejamento. Porto Alegre: CirKula, 2016, p. 197-214.

; SERPA, Claudia Brandão; FERNANDES, Edésio; COSTA, Fernanda Carolina Vieira da; GRAZIA, Grazia de; SAULE JR., Nelson; LEÃO JR., Paulo Silveira Martins; ROLNIK, Raquel (Coords.). Regularização da terra e moradia: o que é e como implementar. São Paulo: Instituto Polis, 2002.

ALFONSIN, Jacques. O Acesso à Terra como Conteúdo de Direitos Humanos Fundamentais à Alimentação e à Moradia. Porto Alegre: Sérgio Fabris, 2003.

ATLAS DO DESENVOLVIMENTO HUMANO NO BRASIL. São Leopoldo, RS. 2020. Disponível em: <http://atlasbrasil.org.br/2013/pt/perfil_m/sao-leopoldo_rs>. Acesso em: 2 jun. 2020.

BRASIL. Constituição da República Federativa do Brasil, de 5 de outubro de 1988. Disponível em: <http://www.planalto.gov.br/ccivil_03/Constituicao/Constituicao.htm>. Acesso em: 2 jun. 2020.

BRASIL. Instituto de Pesquisa Econômica Aplicada (IPEA). Nota Técnica Estimativas do déficit habitacional brasileiro (2007-2011) por municípios (2010). Brasília, maio 2013. Disponível em: <http://www.ipea.gov.br/portal/images/stories/PDFs/nota_tecnica/130517

_notatecnicadirur01.pdf>. Acesso em: 2 jun. 2020.

. Lei n ${ }^{\circ} 10.257$, de 10 de julho de 2001. Regulamenta os arts. 182 e 183 da Constituição Federal, estabelece diretrizes gerais da política urbana e dá outras providências (2001). Disponível em: <http://www.planalto.gov.br/ccivil_03/LEIS/LEIS_2001/L10257.htm>. Acesso em: 2 jun. 2020.

. Lei $\mathrm{n}^{\circ}$. 10.406, de 10 de janeiro de 2002. Institui o Código Civil (2002). Disponível em: <http://www.planalto.gov.br/ccivil_03/LEIS/2002/L10406.htm>. Acesso em: 2 jun. 2020.

Lei $n^{\circ}$. 13.465/2017. Dispõe sobre a regularização fundiária rural e urbana, sobre a liquidação de créditos concedidos aos assentados da reforma agrária e sobre a regularização fundiária no âmbito da Amazônia Legal; institui mecanismos para aprimorar a eficiência dos procedimentos de alienação de imóveis da União; altera as Leis n os 8.629, de 25 de fevereiro de 1993 , 13.001, de 20 de junho de 2014 , 11.952, de 25 de junho de 2009, 13.340, de 28 de setembro de 2016, 8.666, de 21 de junho de 1993, 6.015, de 31 de dezembro de 1973, 12.512, de 14 de outubro de 2011 , 10.406, de 10 de janeiro de 2002 (Código Civil), 13.105, de 16 de março de 2015 (Código de Processo Civil), 11.977, de 7 de julho de 2009, 9.514, de 20 de novembro de 1997, 11.124, de 16 de junho de 2005, 6.766, de 19 de dezembro de 1979, 10.257, de 10 de julho de 2001, 12.651, de 25 de maio de 2012, 13.240, de 30 de dezembro de 2015, 9.636, de 15 de maio de 1998, 8.036, de 11 de maio de 1990, 13.139, de 26 de junho de 2015, 11.483, de 31 de maio de 2007, e a 12.712, de 30 de agosto de 2012, a Medida Provisória no 2.220, de 4 de setembro de 2001, e os Decretos-Leis $\mathrm{n}^{\circ}$ 2.398, de 21 de dezembro de 1987, 1.876, de 15 de julho de 1981, 9.760, de 5 de setembro de 1946, e 3.365, de 21 de junho de 1941; revoga dispositivos da Lei Complementar $n^{\circ} 76$, de 6 de julho de 1993, e da Lei no 13.347 , de 10 de outubro de 2016; e dá outras providências. Disponível em: <http://www.planalto.gov.br/ccivil_03/_Ato2015-2018/2017/Lei/L13465.htm>. Acesso em: 2 jun. 2020. 


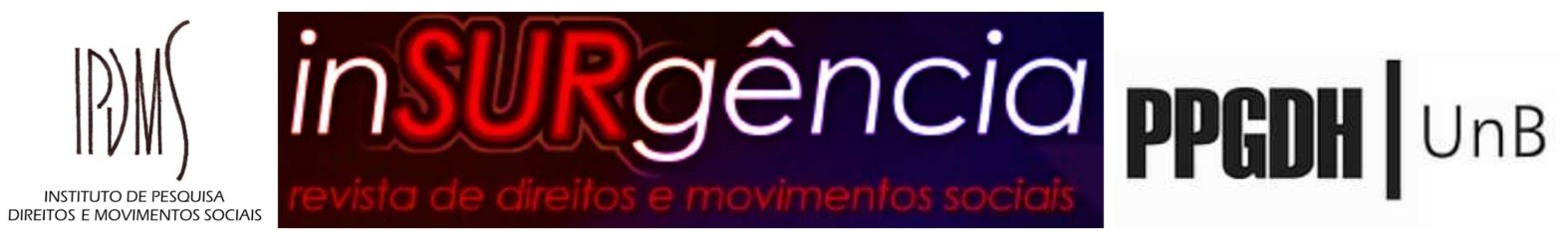

BRASIL. Projeto BRA/05/036 - Fortalecimento da Justiça Brasileira - Convocação 01/12. Área temática: atuação da Justiça nos conflitos fundiários urbanos, esta denominada de "Pesquisa sobre soluções alternativas para conflitos urbanos" (relatório final). São Paulo/Brasília, jul. 2013. Disponível em: <http://cdes.org.br/wpcontent/uploads/2018/10/dialogos-sobre-justica.pdf>. Acesso em: 10 jun. 2020.

BRASIL. Resolução $\mathrm{n}^{\circ}$. 10, de 17 de outubro de 2018. Conselho Nacional de Direitos Humanos, 2018. Disponível em: <https://www.gov.br/mdh/pt-br/assuntos/noticias/todas-asnoticias/2018/outubro/resolucao-para-garantia-de-direitos-humanos-em-situacoes-deconflitos-por-terra-e-aprovada-pelo-conselho-nacional-dos-direitoshumanos/copy_of_Resoluon10Resoluosobreconflitospossessriosruraiseurbanos.pdf>. Acesso em: 10 jun. 2020.

CÂMARA DOS DEPUTADOS. Falta de recursos prejudica o programa "Minha Casa, Minha Vida"; afirmam técnicos em audiência pública. 2019. Disponível em: $<$ https://www2.camara.leg.br/atividade-legislativa/comissoes/comissoespermanentes/cdhm/noticias/falta-de-recursos-prejudica-o-programa-201cminha-casa-minhavida201d-afirmam-tecnicos-em-audiencia-publica>. Acesso em: 10 jun. 2020.

CONCEIÇÃO João; MAIA, Marilene. Vale do Sinos. Aluguel e domicílio precário são responsáveis por $86 \%$ do déficit habitacional. In: Revista IHU On-line. 2018. Disponível em: <http://www.ihu.unisinos.br/167-noticias/observasinos/578874-aluguel-e-domicilio-precariosao-responsaveis-por-86-do-deficit-habitacional-no-vale-do-sinos>. Acesso em: 2 jun. 2020.

ESTADO DO RIO GRANDE DO SUL. Relatório da Missão em Defesa do Direito Humano à Moradia das Ocupações Urbanas da cidade de São Leopoldo/RS. Conselho Estadual de Direitos Humanos. 2019.2 Disponível em: <https://drive.google.com/file/d/1dhAt3U77VMpGw5N_6uVqQYqM-joZVevZ/view>.

Acesso em: 10 jun. 2020.

FALS BORDA, Orlando. Ciencia propia y colonialismo intelectual. México: Nuestro Tiempo, 1970

FÓRUM NACIONAL DA REFORMA URBANA. GT Conflitos: Panorama dos Conflitos Fundiários Urbanos no Brasil. 2019. Disponível em <http://www.cdes.org.br/wpcontent/uploads/2019/11/panorama-dos-conflitos-2018-5.pdf>. Acesso em: 10 jun. 2020.

FERNANDES, Edésio. A nova ordem jurídico-urbanística no Brasil. In: FERNANDES, Edésio. ALFONSIN, Betânia (Orgs.). Direito Urbanístico: Estudos Brasileiros e Internacionais. Belo Horizonte: Del Rey, 2006, p. 3-24.

FUNDAÇÃO DE ECONOMIA E ESTATÍSTICA (FEE). Resumo Estatístico Município: São Leopoldo. 2018. Disponível em: <https://arquivofee.rs.gov.br/perfilsocioeconomico/municipios/detalhe/?municipio=S\%E3o+Leopoldo $>$. Acesso em: 2 jun. 2020.

FUNDAÇÃO GETÚLIO VARGAS (FGV). Análise das Necessidades Habitacionais e suas Tendências para os Próximos Dez Anos. Associação Brasileira de Incorporadoras Imobiliárias - ABRAINC. Produto 2 - Relatório Técnico Final. 17 out. 2018.

FUNDAÇÃO JOÃO PINHEIRO (FJP). Déficit habitacional no Brasil: 2015. 2018. Disponível em:

$<$ http://www.bibliotecadigital.mg.gov.br/consulta/verDocumento.php?iCodigo=76871\&codU suario=0>. Acesso em: 2 jun. 2020. 


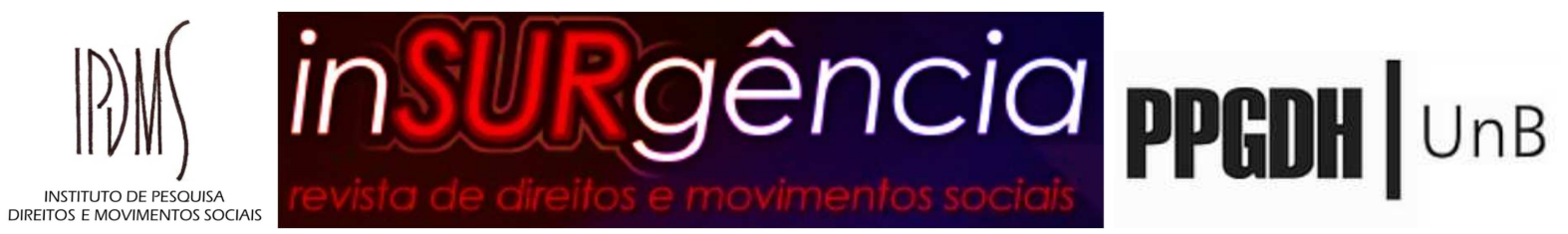

HARVEY, David. Ciudades rebeldes - Del derecho de la ciudad a la revolución urbana. Madrid: Ediciones Akal, 2013.

HOLSTON, James. Cidadania Insurgente. Disfunções da cidadania e da modernidade no Brasil. Trad. Claudio Carina. São Paulo: Companhia das Letras, 2013.

LEAL, Rogério Gesta. Direito Urbanístico: condições e possibilidades da Constituição do Espaço Urbano. Rio de Janeiro Renovar, 2003.

LEFEBVRE, Henri. O direito à cidade. Tradução de Cristina C. Oliveira. Itapevi: Nebli, 2016. LIBÓRIO, Daniela Campos; FROTA, Henrique Botelho; CARDOSO, Patrícia de Menezes; GUIMARÃES, Irene Maestro (Orgs.). Direito Urbanístico em juízo: estudo de acórdãos do Tribunal de Justiça do Estado de São Paulo. São Paulo: IBDU, 2016.

MANIGLIA, Elisabete. O trabalho rural e função social da propriedade. In: Revista de Estudos Jurídicos. Franca, UNESP, ano 5, n. 9, p. 67-74, jan./dez. 2000.

; DOSSO, Taisa Cintra. A Função Socioambiental da Propriedade Rural no Brasil. 2013. Artigo inédito.

MARICATO, Ermínia. Brasil, cidades: alternativas para a crise urbana. 7. ed. Petrópolis: Vozes, 2013.

Por um novo enfoque teórico na pesquisa sobre habitação. In: Cadernos Metrópole, $\mathrm{n}$. 21, jan./jun. 2009, p. 32-52.

MARTINS, Cristina Maria dos Reis. Investimentos em infraestrutura e habitação na Região Metropolitana de Porto Alegre. In: Carta de Conjuntura FEE. a. 26, n. 9, 2017. Disponível em: $<$ http://carta.fee.tche.br/article/investimentos-em-infraestrutura-e-habitacao-na-regiaometropolitana-de-porto-alegre/> Acesso em: 2 jun. 2020.

MOURA, Emerson Affonso da Costa; MOTA, Maurício Jorge Pereira da. O direito à moradia digna na regularização fundiária da Lei Federal n ${ }^{\circ}$ 11.977/2009: o caso do auto de demarcação da Comunidade da Rocinha. In: Revista de Direito da Cidade. v. 7, n. 3, 2015 Rio de Janeiro, p. 1.292-1.310.

MÜLLER, Cristiano. Possibilidades de empoderamento da luta contra os despejos a partir da teoria crítica dos direitos humanos. In: MÜLLER, Cristiano; MOROSO, Karla (Orgs.). Os conflitos fundiários urbanos no Brasil: estratégias de luta contra os despejos e empoderamentos a partir da teoria crítica dos direitos humanos. Porto Alegre: CDES Direitos Humanos, 2014. Disponível em: <http://www.cdes.org.br/wp-content/uploads/2017/10/02artigon08.pdf>. Acesso em: 10 jun. 2020.

OBSERVATÓRIO DA REALIDADE E DAS POLÍTICAS PÚBLICAS DO VALE DO RIO DOS SINOS (OBSERVASINOS). A vida pelo direito a um lar (on line). 27 mar. 2019. Disponível em: <http://www.ihu.unisinos.br/observasinos/vale/moradia/a-vida-pelo-direito-aum-lar>. Acesso em: 2 jun. 2020.

PLATAFORMA DHESCA BRASIL. Desafios dos Direitos Humanos no Brasil e a experiência das Relatorias Nacionais em DHESCA - Informe 2007-2009. Curitiba: Terra de Direitos, 2009.

PREFEITURA DE SÃO LEOPOLDO. 2016. Por que São Leopoldo?? (on line). Disponível em:

http://www.saoleopoldo.rs.gov.br/?template=abreAnexos\&arquivo=8937\&nomeArquivo=PO 


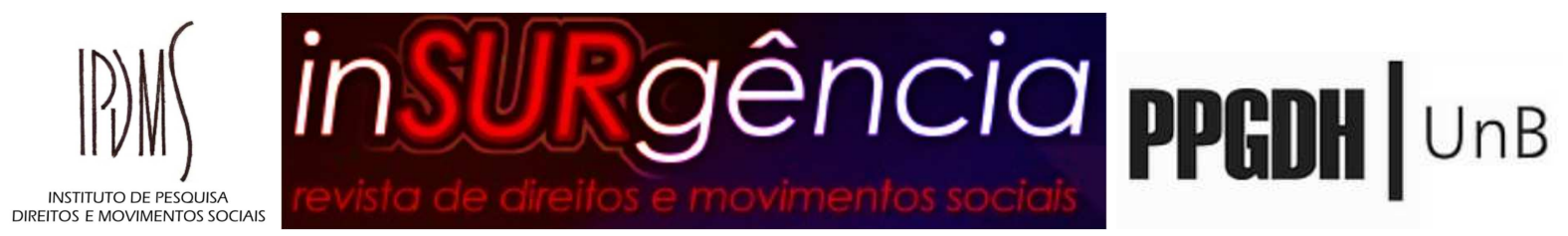

R\%20QUE\%20S\%C3O\%20LEOPOLDO\%20\&categoriaDownload=9>. Acesso em: 2 jun. 2020.

ROLNIK, Raquel. A lógica do caos. Carta na escola. São Paulo, n. 30, p. 24-26, out. 2008.

As vozes das ruas: as revoltas de junho e suas interpretações. In: MARICATO, Ermínia et. al. Cidades Rebeldes: Passe Livre e as manifestações que tomaram as ruas do Brasil. São Paulo: Boitempo, 2013, p. 7-12.

Guerra dos lugares: a colonização da terra e da moradia na era das finanças. São Paulo: Boitempo, 2015.

Para além da lei: legislação urbanística e cidadania (São Paulo 1886-1936). In: SOUZA, Maria Adélia A.; LINS, Sonia C.; SANTOS, Maria do Pilar C.; SANTOS, Murilo da Costa (Orgs.). Metrópole e Globalização - Conhecendo a cidade de São Paulo. São Paulo: Editora CEDESP, 1999.

Estatuto da Cidade - Instrumento para as cidades que sonham crescer com justiça e beleza. In: SAULE JÚNIOR, Nelson; ROLNIK, Raquel. Estatuto da Cidade: novos horizontes para a reforma urbana. São Paulo, Pólis, 2001. xxp. (Cadernos Pólis, 4), p. 5-9.

SAULE JÚNIOR, Nelson. Novas Perspectivas do Direito Urbanístico Brasileiro. Ordenamento Constitucional da Política Urbana. Aplicação e Eficácia do Plano Diretor. Porto Alegre: Sérgio Antonio Fabris Editor, 1997.

SÁNCHEZ RUBIO, David. Crítica a una cultura estática y anestesiada de derechos humanos. Por una recuperación de las dimensiones constituyentes de la lucha por los derechos. In: MÜLLER, Cristiano; MOROSO, Karla (Orgs.). Os conflitos fundiários urbanos no Brasil: estratégias de luta contra os despejos e empoderamentos a partir da teoria crítica dos direitos humanos. Porto Alegre: CDES Direitos Humanos, 2014. Disponível em: $<$ http://www.cdes.org.br/wp-content/uploads/2017/10/02artigon08.pdf >. Acesso em: 10 jun. 2020. 